\title{
Religious change, social conflict and legal competition: the emergence of Christian personal law in colonial India
} NANDINI CHATTERJEE

Department of History, University of Plymouth, Plymouth $\mathrm{PL}_{4} 8 \mathrm{AA}$, United Kingdom Email:nandini.chatterjee@plymouth.ac.uk

\begin{abstract}
One of the most contentious political issues in postcolonial India is the unfulfilled project of a 'uniform civil code' which would override the existing 'personal laws' or religion-based laws of domestic relations, inheritance and religious institutions. If the personal laws are admitted to be preserved (if somewhat distorted) remnants of 'religious laws', then the legitimacy of state intervention is called into question, especially since the Indian state claims to be secular. This paper, by discussing the history of the lesser-known Christian personal law, demonstrates that this conundrum is of considerable heritage. From the earliest days of British imperial rule in India, the quest to establish a universal body of law conflicted with other legal principles which upheld difference: that of religion, as well as race. It was the historical role of Indian Christians to occasion legal dilemmas regarding the jurisdictions of British and 'native' law, and concurrently about the identity of people subject to those different laws. In trying to discover who the Indian Christians were, and what laws ought to apply to them, British judges had perforce to reflect on who the 'British' were, whilst also dealing with conflicting collective claims made by Hindus, Muslims, Parsis, and Christians themselves about their own identity and religious rights. The Indian Christian personal law was an unintended by-product of this process, a finding which throws light both on the dynamics of colonial legislation, and on the essentially modern nature of Indian personal laws.
\end{abstract}

\section{A hapless husband}

In 1870 , a man called Zabardast Khan filed for divorce in the district court of Farrukhabad, a north Indian city. His grounds were desertion and adultery by his wife, and he filed his case under the newly enacted Indian Divorce Act (Act IV of 1869), which was the first statutory 
divorce law of the country. ${ }^{1}$ Despite the language of the legal case (i.e. desertion, adultery), Khan' story was not that of a cuckolded husband, but that of a religious convert caught in personal, social and legal conflicts. Both Khan and his wife were born Muslims, and married as such. Some years after their marriage, they converted to Christianity under the aegis of the American Presbyterian mission. Later, Khan's wife decided to revert to Islam, and subsequently to marry another Muslim man. Khan returned his wife's dower, signifying the end of his relationship with her under Muslim law, and filed for divorce.

In spite of his apparently reasonable plea, Khan lost his case. The district judge felt that the case required the greater expertise of the High Court judges, and the case was transferred accordingly. The High Court of North-Western Provinces at Allahabad found that the Indian Divorce Act could not apply to this case, since that statute was 'intended to apply to such marriages as are recognized as marriages by Christians, and not to polygamous contracts, such as are the unions known as marriages to the Mahomedan law.' Khan was Christian and had married only once, but it was true that he had married under Muslim law, and could have been polygamous had he remained Muslim. ${ }^{2}$ This placed his marriage beyond the scope of British matrimonial law and of the Indian Divorce Act, which was based on the former. As far as Muslim law was concerned, Maulvi Asadullah Khan, earlier Qazi al-Qazat of the Sadr court of NorthWestern Provinces, now Subordinate Judge, ${ }^{3}$ opined on consultation that by Muslim law Zabardast Khan was separated from his wife the

${ }^{1}$ As opposed to traditional provisions within Muslim personal law, as well as various Hindu caste rules.

${ }^{2}$ The notion of 'potentially polygamous' marriage, invalid under British law, was a description that applied even when parties were in fact monogamous. The concept remained operative in Britain as late as 1995, until by the Private International Law (Miscellaneous Provisions) Act 1995 (1995 c 42) s. 5, marriages of persons domiciled in England and Wales performed abroad under laws that permitted polygamy, became valid, provided that polygamy was not actually committed. Halsbury's notes on the law referred to Muslim marriages, performed under Muslim personal law abroad, and the case of Hussein versus Hussein (1983) Fam. 26 in particular. Halsbury's Statutes of England and Wales, (4th ${ }^{\text {th }}$ edn, London: Butterworths, 20o6), Vol. 27, pp. 640-641. The consequences of this legal doctrine were very different for Christians in Britain and in India, as this paper will show.

${ }^{3}$ British Indian courts had Muslim and Hindu law specialists attached to them, in consultative capacity, until such offices were abolished by the Act XI of 1864. However consultation of 'expert witnesses', especially where Muslim law was concerned, continued into the early twentieth century. M.P. Jain, Outlines of Indian Legal History $\left(4^{\text {th }}\right.$ edn, Bombay: N.M. Tripathi, 1981), p. 467 . 
moment he had converted, because by Muslim law an apostate was considered socially dead. But the judges could not let Zabardast Khan avail of the provision of Muslim law either, because he was at the time of the suit a Christian, and had filed his case under the Indian Divorce Act. ${ }^{4}$ Bigamy was a criminal offence for Christians, ${ }^{5}$ so Khan was effectively excluded from marital life until his ex-wife died.

Since the situation was an oppressive one for the principal protagonist, one might be tempted to explain it with reference to deliberate oppression. And since Indian Christians were a small religious minority in India then, as now, the larger religious groups would provide the most satisfying oppressors, the majoritarian agenda being sustained by a colonial British government (and British judges influenced by state imperatives) seeking to secure political security at the expense of religious freedom. In fact, the very few scholars who have attempted to analyse the legal experience of Indian Christians in British India have attributed primary agency to the British government and its political imperatives. Gauri Viswanathan argues that this agency consisted of forcibly applying Hindu personal laws to those Hindus who had converted to Christianity, thereby frustrating their efforts to choose their religious identity. She argues that the British government's motive for doing so derived from the essentially political nature of religious conversions, which simultaneously subverted the self-congratulatory secular national culture emerging in nineteenth-century Britain, and the rigid religiolegal identities imposed in empire. ${ }^{6}$ In response, Chandra Mallampalli questions Viswanathan's premise that Indian converts to Christianity did not wish to have Hindu (or other) personal laws applied to them. Underlining that Christian doctrines do not advocate any particular rules of inheritance, he demonstrates that Indian Christians often claimed the right to continue in their pre-conversion personal law. I believe that Mallampalli takes a much more accurate view regarding the motivations of Indian Christians; in addition, I think that Viswanathan's analysis of Abraham is flawed, because she fails

${ }^{4}$ Zaburdust Khan versus his wife, N.W. Provinces High Court Reports, Vol. II (Allahabad: N.W. P. Government Press, 1870), pp. 370-379.

${ }^{5}$ Unlike all other Indian males, except Parsis, after the passing of the Parsi Marriage and Divorce Act, XV of 1865.

${ }^{6}$ Gauri Viswanathan, Outside the Fold: Conversion, Modernity and Belief (Princeton: Princeton University Press, 1998), pp. 75-117. Chandra Mallampalli, Christians and Public Life in Colonial South India I 863-1937: Contending with Marginality (London: Routledge, 2004), pp. 21-8o, especially with regard to inheritance laws, pp. $3^{8-5} 8$. 
to take into account the Indian Succession Act of 1865 , which was legislated two years after Abraham, with the intention of providing a uniform inheritance law for Indian Christians thereafter. If the colonial government played an insidious role in this context, it certainly did not consist of denying Christians a distinct personal law.

How did this new inheritance law, an important part of the emerging Christian personal law, come about? Mallampalli, who is aware of the novelty of Christian personal law itself, suggests that it was largely an arbitrary imposition: the new inheritance law, and indeed the entire personal law for Indian Christians, consisting of laws regarding marriage, divorce, inheritance and guardianship, was created by the British rulers because of their misplaced effort to rescue converts from social oppression, as well as their rigid view of Indian religious identities. The effect of such state action was the isolation of Indian Christians from the rest of Indian society, and their marginalization. My analysis is different; while I concur with Mallampalli that the Christian personal law of India did not emerge as a result of demands from Indian Christians themselves, I cannot fully subscribe to the view that it was a unilateral creation by the colonial government.

For example, Mallampalli himself pays a great deal of attention to social conflicts derived from religious change, especially between increasingly nationalized Hindus, and those who were deemed to have 'deserted' their families and nation by converting to Christianity. But he does not connect his narration of socio-political contests with the history of legislation-never asking, for example, whether the colonial government could have continued to apply Hindu and Muslim personal laws to those who had become Christian, given that the families of such 'converts' refused to allow them a share in familial estates. Such exclusion from kinship and property entitlements was perpetrated by personal violence as well as by legal battles, all closely watched by the increasingly 'nationalized' Hindu and Muslim religious communities. The exercise of imperial power was in the last resort coercive, but this did not preclude systematic efforts at creating consensus, among other things by ostentatiously 'preserving' the religious laws of Indians. This paper deals with legal efforts in British-ruled India to reconcile two legal and political principles: the principle of preserving indigenous laws, which had developed as a colonial tradition from the lateeighteenth century, and the principle of religious freedom, which came to the fore in the early-nineteenth century due to the appeals of Christians (European and Indian), and was later appropriated by other religious communities in India. I argue that the result of this 
legal conflict was not simply an expedient division of legal spheres: indigenous law in the private sphere and English law or its derivatives in the public sphere, ${ }^{7}$ but a complex and unstable legal system, constantly evolving through the interaction between British legal ideas and a variety of competing Indian legal claims. One by-product of this process was the novel Christian personal law.

This is not, however, a narration of the mathematical resolution of legal puzzles: it is a social and political history, and an analysis of how certain legal principles were adopted by a range of Indian actors to assert their claims on the state. Above all, it is a history of Indian Christians, one that attempts to look beyond the usual narrative of victimization and resistance. It is true that Indian Christians occupied a subaltern position within a number of hierarchies: within their own racially ordered churches, within the emerging Indian nation, and for dalit Christians, within their caste-divided community. For that very reason, and because the notion of a homogenous subaltern agency and consciousness is much more difficult for historians of India to accept today than it was twenty years back, it is worth examining how 'Indian Christians' became just that-Indian Christians, in a period when the

${ }^{7}$ David Washbrook encapsulated the dynamic tension produced by this division by referring to the 'Janus-faced' nature of the colonial legal system, which, by embedding ascribed status in personal/private law, hobbled the possibility of an homogenous rule of law even in the public realm, particularly with regard to property rights. Washbrook's analysis of Indian personal law is much more historically situated than that of most legal scholars, including Derrett, whose work he relied upon. David Washbrook, 'Law, State and Agrarian Society in Colonial India' in Modern Asian Studies, Vol. 15, No. 3 (1981), pp. 649-721; J. D. M. Derrett, Religion, Law and the State in India ( $2^{\text {nd }}$ edn, New Delhi: Oxford University Press, 1999). The present paper highlights issues that Washbrook did not contend with, firstly, the ubiquity of status in public law, not simply as a spillover from the personal law, but inherently, through the implication of racial difference. Elizabeth Kolsky has pointed to the claim made by white supremacists that they were entitled to a distinct criminal procedure as a 'personal law'. Elizabeth Kolsky, 'Codification and the Rule of Colonial Difference: Criminal Procedure in British India' in Law and History Review, Vol. 23, No. 3 (September 2005), pp. 631-683. This paper attempts to connect the realms of public and private law, and the apparently distinct legal claims to racial and religious status by narrating the history of such persons who simultaneously invoked all these categories: the Indian Christians. Secondly, due to the nature of the questions asked, Washbrook's analysis had little time for tracing the ideological differences among British legislators and judges regarding the legal approach to religious difference. This is the subject of the present paper, which also draws on recent discussions of the theme in Lauren Benton, Law and Colonial Cultures: Legal Regimes in World History, I $400-$ I9oo (Cambridge: Cambridge University Press, 2002); and Robert Travers, Ideology and Empire in Eighteenth-Century India: the British in Bengal (Cambridge: Cambridge University Press, 2007). 
idea of India was being intellectually and politically negotiated, at the same time as nation-like religious communities were being imagined. ${ }^{8}$

The distinctiveness of the history of Christian personal law (as opposed to the other personal laws) lies in its overlap with the history of racial demarcation in India. Religious status and matrimonial law being inseparable in eighteenth- and nineteenth-century British law, early legislation about Christian marriage in India consisted of British concerns about their own domestic and property relations. During such legal episodes, when English ecclesiastics, law lords and Parliament ploughed in, Indians remained marginal to the legislating vision, even if Indian Christians were the majority of people to whom a Christian marriage law would apply. But the conflation of race and religion was uncomfortable, especially because of the vocal presence of missionaries who constantly produced petitions regarding the plight of Indian Christians, which could prove embarrassing political material back in Britain. The government was also highly aware that there were people whose lives and genealogies undermined binary categorizations of 'British' or 'native'. Through their very lives, Armenians, Indiaborn Portuguese, Indo-Portuguese, and Anglo-Indians ${ }^{9}$ as well as converts from Hinduism, Islam and Zoroastrianism, forced the state to repeatedly consider the nature of racial distinctiveness, which underwrote the hierarchical order of civic status within the colonial legal and political systems.

Other than competition between the emerging Indian religious communities, and British efforts to resolve the question of their own identity, there was a third factor that shaped the Indian Christian personal law, and this consisted of negotiation of the legal system by Christians themselves. From the eighteenth century until recent times, Christians in India did claim (unlike what Mallampalli would have us believe) distinct laws based on religious and/or

${ }^{8}$ Benedict Anderson's notion of the modern community appears eminently applicable not only to those collectives which emerged as nation-states, but also to religious collectives with similar territorial vision which did not in all cases coincide with a national reality. Benedict Anderson, Imagined Communities: Reflections on the Origin and Spread of Nationalism (London: Verso, 1983).

${ }^{9}$ In the contemporary sense of a child of a British father and an Indian mother, rather than British expatriates in India, although these two social categories were not nearly as distinct as the latter desired them to be. See Elizabeth Buettner's discussion of how the 'return' of British children for education to Britain, was essential for securing their "white' identity. "Not Quite Pukka": Schooling in India and the Acquisition of Racial Status', in Elizabeth Buettner, Empire Families: Britons and Late Imperial India (Oxford: Oxford University Press, 2004), pp. 72-109. 
racial status. Such claims were sometimes made collectively, and especially from the second half of the nineteenth century, such claims provided unifying agendas for new territorially-spread community organizations with significant lay leadership and participation. These 'communal' demands were shaped in the existing language of personal laws and community rights which appeared intelligible to a large number of Indians and British in the late nineteenth century. But the paradox for Indian Christians was their need to combine their claim to distinctiveness with that of multiple belonging, which alone gave substance to the right of free, i.e. unpunished religious choice. Because if a convert from Hinduism or Islam to Christianity was not to be deprived of her or his inheritance, such a person had to be permitted to be a Hindu or Muslim, at least occasionally, for legal purposes.

Such paradoxical claims were creatively deployed during disputes at the inter-personal level which took place within Indian families, and often over property rights. In such disputes different members of the same family claimed different religious, and hence legal status, and this was the case not only when a member of the family had converted to Christianity, but when the entire family was Christian, and had been so for several generations. The notion of 'conversion', and the official assumption that Indian Christians were inevitably 'converts' from a pre-existing religio-legal state provided particularly convenient tools for certain kinds of patriarchal agendas. Certain Christian men utilized legally comprehensible claims to a fictive past which was nonChristian, premised on the legal provision of non-discrimination for religious change, in order to deprive female members of the family of legal entitlements which would otherwise have been theirs. If these paradoxical collective and individual demands did not in themselves create the Christian personal law, they did adopt it, and take it into directions where we find it today.

For it is also essential to connect the history of Christian personal law with the contemporary debates about these laws, whose gender inequity surfaced into Indian political consciousness only in the 1990s. ${ }^{10}$ Although (thankfully) Christian personal law never entered the political limelight like Muslim personal law, any examination of

${ }^{10}$ In 1990, a Christian woman called Mary Sonia Zachariah could not get divorced on the basis of physical cruelty, since the Indian Divorce Act 1869, which applied to Christians, required adultery of the spouse in all cases, but coupled with an aggravating cause, such as cruelty, for the wife. The Kerala High Court found this unconstitutional gender discrimination, and recommended legislative action, failing which, it declared the law unconstitutional in 1995. A similar judgement was received 
the debates preceding and following marriage reform legislation in $2001^{11}$ shows that the parallel between religion versus women's rights, and personal laws versus uniform civil code has become generalized in Indian thought. Fortunately for us, the unhappy life of Zabardast Khan forces us to reconsider such patterns. For here we have a man oppressed neither by 'tradition' nor by 'modernity' but apparently, by falling in between both. Since he happened to be a male protagonist caught in a non-existent marriage because of unfair marriage and divorce laws, his case became iconic for men who attempted to represent and lead a Christian political community in the earlytwentieth century. The earliest calls for reforming 'Christian personal law' came not from women oppressed by tradition, but by men, who found the reason for their victimization in their political weakness.

In broader terms, this paper investigates British religious policy in India, which has been little explored, the official self-description of 'neutrality' being taken to mean an unproblematic disengagement from religion, ${ }^{12}$ the purpose of such disengagement being attributed, by some scholars, to an imperial legitimation project. ${ }^{13} \mathrm{I}$ will show that the insipid term 'neutrality' has concealed a complex baggage of substantive law and policy relating to religion, which the postcolonial Indian state inherited from its colonial predecessor. It is my argument

in the Bombay High Court in 1997. Flavia Agnes, Law and Gender Inequality: the Politics of Women's Rights in India (New Delhi: Oxford University Press, 1999), pp. 154-156.

${ }^{11}$ See Religion and Society, Special issue on the Uniform Civil Code, 43: 3 (September 1996), which brought together the opinions of the most committed Christian advocates of reform, including Jyotsna Chatterji, as well as more critical views. The Indian Divorce (Amendment) Act 2001 modified the Special Marriage Act 1954, Hindu Marriage Act 1955, the Parsi Marriage and Divorce Act 1936 and the Indian Divorce Act 1869, the last being relevant to Christians. 'Marriage law reforms', Government of India, Press Information Bureau. Visit http://pib.nic.in/feature/feyr2001/fnov2001/f22112001 $1 . h t m l$, last accessed 15 December 2009. Many Christian activists perceived the legislation to be skewed, and imposed with undue haste by a BJP-led government. See John Dayal, A Matter of Equity: Freedom of Faith in Secular India (New Delhi: Anamika, 2007), pp. 222-23o.

12 The standard periodization posits a period of intense Evangelical Christian (combined with secular Utilitarian) influence on British imperial policy in the first half of the nineteenth century, followed by the 'Mutiny' of 1857 , which was interpreted widely as a religious reaction from Indians, and which apparently led to a settled policy henceforth of non-interference in religion. Eric Stokes, The English Utilitarians and India (Oxford: Clarendon, 1959); Thomas Metcalf, Aftermath of Revolt: India I $857-$ 70 (Princeton: Princeton University Press, 1964).

${ }^{13}$ Gauri Viswanathan, Masks of Conquest: Literary Studies and Colonial Rule in India (New York: Columbia University Press, 1989); Gerald Studdert-Kennedy, Providence and the Raj: Imperial Mission and Missionary Imperialism (New Delhi, London: Sage, 1998). 
that awareness of this history can permit us to step beyond the somewhat reified discussions regarding the suitability and success of secularism in India. ${ }^{14}$ One can only hope that it would also encourage thought regarding legal conundrums in post-imperial Britain, where efforts to secure racial justice and religious freedom appear to be grappling unevenly with the categories of 'religion' and 'race'. ${ }^{15}$

\section{Personal laws and the uniform civil code: an old contradiction}

India has four personal laws, Hindu, Muslim, Christian and Parsi, ${ }^{16}$ which apply to a person depending on his/her religious identity, and travel with him/her wherever he/she goes within the country, as opposed to laws that are of territorial application. ${ }^{17}$ The Hindu, Muslim, Christian and Parsi personal laws deal with marriage, divorce, inheritance, guardianship, and religious endowments of those legally defined as Hindus, Muslims, Christians and Parsis. During judicial consideration of any such dispute, determination of a person's religious identity is essential in order to establish the relevant law. Lack of religious identity is simply not an option, even if the persons in question do not practise or believe in any religion. ${ }^{18}$

${ }^{14}$ Rajeev Bhargava (ed.), Secularism and its Critics (New Delhi: Oxford University Press, 1998).

${ }^{15}$ Geoffrey Bindman, 'From Race to Religion: the Next Deterrent Law?' http://www.opendemocracy.net/faith-europe_islam/article_2049.jsp, last accessed 15 December 2009. Bindman was legal adviser to the Commission for Racial Equality, involved in a case in 1982-1983 about a Sikh boy Gurinder Singh Mandla, who was refused permission to attend his private school if he wore his turban. Mandla's case for discrimination failed in the county court and the Court of Appeal, where it was stated that only racial discrimination was actionable, not religious discrimination. The House of Lords reversed these decisions in favour of Mandla, deciding that Sikhs were a 'race' rather than purely a 'religion'.

16 The last applying to Zoroastrians of Persian origin, known in India as 'Parsis'.

17 G.C. Rankin, 'The Personal Law in British India' in Journal of the Royal Society of Arts, Vol. 89 (May, 1941), pp. 426-442.

${ }^{18}$ With the Hindus, the label includes those that are heterodox in their beliefs, support non-Hindu religious groups or are socially and ritually ostracized from a Hindu caste/sect/group. As Marc Galanter explains, the definition of 'religious identity' is in reality a description of civil status, not of religious belief or social behaviour. Marc Galanter, 'Hinduism, Secularism and the Judiciary', in Marc Galanter, Law and Society in Modern India (New Delhi: Oxford University Press, 1997), pp. 237-258, at p. $24^{1}$. Similarly, a person is assumed to be Muslim if his or her father is Muslim, unless he or she explicitly renounces the faith. Asaf A.A. Fyzee, Outlines of Muhammadan Law $\left(4^{\text {th }}\right.$ edn, New Delhi: Oxford University Press, 1999), pp. 6o-64. 
In that curious section of the Indian Constitution called the 'Directive Principles', which are non-judiciable, and represent the aspirations of the India's constitution-makers, is stated the aim of establishing a uniform civil code. The rhetorical appropriation of the uniform civil code project by right-wing Hindu majoritarian politics, including that of the Bharatiya Janata Party (BJP), has created an apparently irresoluble contradiction for feminists, who are naturally critical of the patriarchal nature of the personal laws, but are unwilling to be used as pawns in the baiting of minorities, especially Muslims, whose personal laws are projected by the BJP as an example of their excessive privilege. ${ }^{19}$

While contemporary Indian feminists are troubled with the apparent opposition between gender-justice and religious freedom, it is very rarely noticed that the legal opposition between personal laws and uniform civil laws has a long history, and is not the product of the growing strength of women's movements. The legal debate over uniform laws and personal laws did not begin in the 1940s, as Sangari states, but at least as early as the 1840 os, and perhaps even the 173 os, as this paper will demonstrate. Since the early eighteenth century, British judges, statesmen, and later legislators contended with the same dilemma in attempting to reconcile the principle of a universal rule of law with what they saw as the requirements of existing indigenous laws. The difference is that in the eighteenth- and nineteenth-century debates, the foremost concern was not women's rights, but the nature of rights that could appertain to persons, who did not comfortably fit the legally defined categories of Muslim or Hindu, nor the relatively vague one of 'British'. Since the earliest Indian claims to the protection of a universal law, transcending religious differences, were made by Indian Christians, it is an historical irony that this effort led to the creation of Christian personal lawapparently another addition to the existing repertoire of fragmented indigenous laws. And yet, the definition of the legal universal was itself historically contingent (indeed for a long time it was unsure whether the universal was Mughal law or British law), and the Indian Christians' demands for it were shaped by their particular social and legal circumstances. At the centre of the process whereby Christians in India acquired a 'personal law' stands the state. By describing that process, this paper attempts to question the view that personal laws

${ }^{19}$ See Kumkum Sangari, 'Gender Lines: Personal Laws, Uniform Laws, Conversion', Social Scientist, Vol. 27, Nos 5/6 (May-June, 1999), pp. 17-61. 
are religious laws in any straightforward sense, preserved (if very badly) against the incursions of legal universalism through a debatable combination of indigenous activism and colonial solicitiousness. ${ }^{20}$ This paper will instead highlight the active role of the colonial state in refereeing competing legal claims to produce the personal laws, which were ultimately state-sanctioned and state-dispensed laws, although theoretically of religious origin, alongside a universal law transcending religious difference.

\section{Conversion, religious law, and natural law in eighteenth-century Bombay}

Christian personal law, as recognized today in India, consists of statutes enacted in the second half of the nineteenth century. ${ }^{21}$ These statutes did not simply recognize a religious tradition that had been somehow overlooked in the original accounting, but were in every sense a legal innovation. Such innovation did not however take place in a vacuum - the statutes were the result of legal conundrums created by disputes in which Christians of India were involved. This section offers a glimpse of such disputes from the early eighteenth century and looks at British legal attempts to resolve them. This will illustrate the "precolonial ${ }^{22}$ British patterns of legal thought and practice which, on the acquisition of greater political power and judicial responsibility, led to the creation of the four personal laws, and in particular, of Christian personal law.

The sources of British judicial authority in early eighteenth-century India were unclear and often conflicting; only in very limited locations could such authority be traced to a recognizable sovereign, such as the British Crown or the Mughal emperor. The Mayors' Courts of the three coastal settlements, established by Royal Charter in 1726 , were Crown courts, deriving authority from the British sovereign, and as such,

${ }^{20}$ For the argument that state-centred legal pluralism was distinctly modern, and that it did not consist of 'stacked' laws with clearly distinguished spheres, see Lauren Benton, Law and Colonial Cultures, pp. 1-3o.

21 The Indian (Christian) Marriage Act 1872, Indian Divorce Act 1869 (amended 2001), Indian Succession Act 1865 , and Guardians and Wards Act 1892.

${ }^{22}$ In the sense that the British then possessed an unsubstantial political role. 
were meant to apply British law, or more accurately, English law. ${ }^{23}$ At Madras and Calcutta, these tribunals were often in formal conflict with Company officials acting as zamindars, a position that officially derived authority from the Mughal emperor. ${ }^{24}$ But the problem was not simply one of institutional multiplicity-even in Bombay, which was officially Crown territory gifted to the Company, there were disputes among the British regarding the legitimate method of dealing with religious differences in law, in the context of India.

In June 1730 , a widow called Zanocky (probably Janki) complained to the English Mayor's Court in Bombay city that her kinsman, 'Bendu' said to be of the taylor [sic] caste, had refused to return to her certain valuables that she had given to him for safekeeping. Bendu, appearing in court on 24 June, responded that, since he had taken care of Zanocky's son for six years, when Zanocky was taken as prisoner to Goa by the Portuguese (and had become Christian), he should be financially compensated for his expenses. The court thought this reasonable, but the case grew more complicated when Zanocky's attorney complained that Bendu was also guilty of withholding from her the custody of her son, on grounds that she had become Christian. Zanocky's son, a boy of twelve called Lachmana (Lakshmana) was summoned to court where he stated that he did not wish to become Ghristian nor live with his mother, but the Mayor, Edward Page, ordered the boy to be returned to Zanocky, while warning her not to force him in matters of religion. Zanocky pledged that she would not, promising to house her son in a 'Gentue'(Gentoo, i.e. Hindu) house. ${ }^{25}$

${ }^{23}$ C. J. B. Larby, 'The Centenary of the High Courts of Calcutta, Bombay and Madras' in The International and Comparative Law Quarterly, Vol. 1 2, No. 3 (July, 1963), pp. $1044^{-1048 .}$

${ }^{24}$ The sale deed executed between the Mughal provincial government and the Company during the transfer of the zamindari of Calcutta in 1694 did not explicitly mention judicial powers, except perhaps with reference to the Company being accorded talluqdar status. Farhat Hasan, 'Indigenous Cooperation and the Birth of a Colonial City: Calcutta, c. 1698-1750' in Modern Asian Studies, Vol. 26, No. 1, (February 1992), pp. $65-82$, at p. 69. This revealed a certain Mughal approach to legal authority: the police and judicial powers which all Mughal zamindars exercised, were implicitly acknowledged rather than formally delegated to these 'little kings'. On zamindars under Mughal rule, and their legal powers, see Radhika Singha, A Despotism of Law: Crime and Justice in Early Colonial India (New Delhi: Oxford University Press, 1998), pp. 1-6. At the same time, such informal legal delegation proved to be a potent source of jurisdictional conflict.

${ }^{25}$ Register of Proceedings of the Mayor's Court, BombayJanuary-September 1830 , p. 120, P/416/103, Asia, Pacific and Africa Collections, British Library, London (henceforth, APAG). 
Bendu was not satisfied, and neither were other members of the caste, who further alerted the Mayor when Zanocky failed to keep her promise and took her son to her own house. At the next session of the Mayor's Court, on 29June, the Mayor read a letter from the Governor of Bombay, Robert Cowan, rebuking the court for usurping jurisdiction that did not belong to them, by interfering in what was a matter of caste customs. ${ }^{26}$ The Mayor wrote back that the case was a civil one, and hence certainly within their jurisdiction, as opposed to a criminal or an ecclesiastical cause. In their view, their decision derived indisputably from the natural right of a parent over a child, according to the natural law theorists Hugo Grotius and Samuel Pufendorf. ${ }^{27}$ This right consisted of authority over a child until the child attained the age of judgement. In addition, the involvement of disputes over property made it a civil case, and the Mayor's Court was not deterred from taking cognizance of it by caste issues being involved. ${ }^{28}$

The Governor responded with great irritation that the Mayor had got both the classification of the case, and the relevant law wrong. Since the Mayor's Court had confessed to not possessing ecclesiastical jurisdiction, they should have refrained from interfering in a religious dispute, since caste was at the core of Hindu religion. As far as the law was concerned, Grotius or Pufendorf would accept that the natural right of the parent could be superseded under certain circumstances, Pufendorf in particular having mentioned the very different customs among the Romans and the Thebans. Had the revered Pufendorf known as much about the Hindus, he would certainly have mentioned them as another (valid) variation. What Pufendorf had failed to do, Cowan proceeded to rectify, informing the court that with Hindus, parental rights ended absolutely when the parent changed his or her religion. Whether or not such custom was laudable, it was the law, since the Company directors had instructed full respect to native customs, i.e. recognized them as law. Hence in returning the Hindu boy to his Christian mother, the Mayor had violated the law. ${ }^{29}$ Page took the matter to the Court of Directors in England, lodging a formal

${ }^{26}$ Bombay Public Proceedings, 26 June 1730 , P/341/7, pp. 75-8o, APAC.

${ }^{27}$ For a discussion of natural law theory, especially as developed by Pufendorf's disciples in the late seventeenth and early eighteenth centuries in Europe, see T. J. Hochstrasser, Natural Law Theories in the Early Enlightenment (Cambridge: Cambridge University Press, 2000).

${ }^{28}$ Register of Proceedings of the Mayor's Court, Bombay 1 July 1 830, pp. 140-144.

${ }^{29}$ Bombay Public Proceedings, 10 July 1730 , pp. 89-95. 
complaint against Cowan, which was investigated by the Committee of Correspondence. ${ }^{30}$

The Bombay Mayor's Court continued to give trouble in the following years, by insisting that Hindu interpreters and witnesses swear with their hands on a cow rather than on the Bhagavad Gita, and holding up proceedings when they refused to do so. ${ }^{31}$ Such creative efforts to accommodate 'native custom' within common law were discouraged by a Dispatch in 1731 from the Court of Directors, which instructed the Mayor's Courts to restrict themselves to English law, leaving the 'natives' to decide their own disputes, unless they voluntarily chose to come to the English court, in which case English law was to apply. ${ }^{32}$ Further discontent in Madras over forms of oathtaking led to explicit exemption of 'natives' from the jurisdiction of the Mayor's Courts (except where they chose to submit to it) when their Charter was renewed in $1753 \cdot{ }^{33}$ In spite of this, Indians continued to provide the bulk of these courts' business, perhaps for lack of an equally effective alternative. ${ }^{34}$

\section{Separating laws, sorting people: Mayor and zamindar in eighteenth-century Calcutta}

At Calcutta, the claim of the British zamindari to be an alternative 'native' tribunal did not prevent jurisdictional conflict, and only

${ }^{30}$ Court Book, April $173^{\circ}$ to March 1 732, B/61, pp. 483, 509-510, APAC.

31 Their efforts make sense in the context of David Lieberman's discussion of the efforts of late-eighteenth-century British jurists to override the rules of evidence in English common law, whereby an infidel who could not swear a Christian oath, had no locus standi in court. Lieberman discusses how natural law was used to argue for an universal rule of evidence beyond (religious) prescriptions that obviously deterred the course of justice; the Mayors' Courts efforts in India seemed not so much to override religious law, as to expand it beyond Christianity, a radical innovation which has received little attention from historians. David Lieberman, The Province of Legislation Determined: Legal Theory in Eighteenth-Century Britain (Cambridge: Cambridge University Press, 1989), pp. 88-98.

${ }^{32}$ Charles Fawcett, The First Century of British Justice in India (Oxford: Clarendon, 1934), pp. 222-224.

33 Courtenay Ilbert, 'Application of European Law to the Natives of India' in Journal of the Society of Comparative Legislation, Vol. 1 (1896-1897), pp. 212-226, at p. 213.

${ }^{34}$ Derrett suggested that the attraction of British courts derived from their being less arbitrative, and hence able to provide a more conclusive victory than a traditional forum which attempted to restore social harmony rather than rigidly separate right from wrong. J. D. M. Derrett, 'The Administration of Hindu Law by the British', Comparative Studies in Society and History, Vol. 4, No. 1 (1961), pp. 10-52. 
showed that such conflicts did not derive merely from institutional flaws or improper legal comprehension, but from the very impreciseness of classificatory categories, in particular, race. Race, in the sense of observable and biologically inherent differences between people, was repeatedly deployed in eighteenth-century judicial disputes, during efforts to separate British law from Indian law, and an amorphous category of people called 'British subjects' from Indians. It proved to be an inadequate measure in both cases.

In $1755, \mathrm{~J}$. Z. Holwell, as zamindar of Calcutta, heard a case, consisting of a plaint by a woman called Phoebe and her husband, Mons. Demontaguy [sic], against Sarah, Phoebe's mother, seeking the restitution of certain jewellery and other valuables deposited with the older woman before Phoebe's marriage. Sarah stated that the property in question had been deposited with her for the maintenance of her grandchild, Phoebe's daughter by her first marriage. Since she had no documents to prove this assertion, Holwell decreed that the property should be delivered to his court, and transferred the same to Phoebe and her husband. Very soon afterwards, Holwell received a summons from the Mayor's Court, which, on Sarah's plaint, accused him of overstepping the powers of his office (by taking note of a case involving British subjects) and ordered him to return the valuables in question. Holwell complained to the Governor's council (of which he was a part) that Sarah was no more than a 'black Fringy'35 and that his appearance in court as defendant for an action performed in his capacity as zamindar would undermine the dignity of his office. ${ }^{36}$ In a longer petition addressed to Governor Drake he argued that even if he had infringed on the jurisdiction of the Mayor's Court, the appeal should lie with the Council and not the Mayor, who was judge of another court of equivalent status. But, he argued, he had not in fact overstepped his authority by hearing a dispute involving an European Christian (Phoebe's husband) and two 'Mustee' Christians, ${ }^{37}$ since the zamindar's court had on earlier occasions heard complaints of Europeans against natives, whether 'Bengallers' (Bengalis) or 'Mustee Fringys' and 'Fringy against Fringy'. ${ }^{38}$ The Council sided with Holwell,

${ }^{35}$ Indian corruption of 'Frank', i.e. European, but used by Holwell in the sense of a mixed-race person of partial European ancestry.

${ }^{36}$ W. K. Firminger, 'Some Records Illustrative of the Mayor's Court-II', Bengal: Past \& Present, Vol. 10 (January-June 1915), pp. 123-145, at pp. 124-125.

37 A term that the compiler (Firminger) glossed as a corruption of mestiço, or 'mixed' in Portuguese.

${ }^{38}$ Ibid., pp. 128-31. 
and wrote to the Mayor's Court requesting withdrawal of the citation, asserting that any complaint against the zamindar had to be made before the Council.

The Council was in reality divided-the only two members with previous experience as zamindar stating that a case involving 'Portuguese' was cognizable by the zamindar, but perhaps not one in which a 'European' was the plaintiff. ${ }^{39}$ The Mayor's Court itself wrote back claiming full jurisdiction over cases of 'Meum and Tuum' where His Majesty's subjects were concerned. They also declared themselves unable to locate the source of the zamindar's judicial authority, since it was not mentioned in the Charter of 1753. In their opinion, Holwell was duty-bound to produce the valuables he had illegitimately dispensed with. ${ }^{40}$ Holwell was deeply indignant; he pleaded inability to go about his business as zamindar if subjected to such restrictions, and produced a table of plausible racial combinations, asking the Council whether he could in future deal with cases involving:

$1^{\text {st }}$ Complaints fil'd by British subjects or Europeans against Hindoos \& Mussellmen in matters of Meum \& Teum

2dly. Fil'd by British subjects or Europeans against Fringys

3dly. " by Fringy against Fringy

4 thly. " by British subjects or Europeans against Armenians

5 thly. " by Armenian against Armenian

6thly. " by Armenian against Hindu and Mussellmen

7thly. " by Armenian against Fringy

8thly. " by Fringy against Armenian

9thly. " by Hindoos \& Mussellmen against Armenian and Fringys

1 othly. " by Fringys against Mussellmen and Hindoo's. ${ }^{41}$

Having produced this table of combinations, Holwell also provided a number of detailed glosses, explaining what the word 'Fringy' meant, and a legal argument:

... black Mustee Portugueze Christians residing in the Settlement as a people distinct from the natural \& proper subjects of Portugall \& as a people who sprung originally from Hindoo's and Mussellmen \& who by the Law of Nations canott $[s i c]$ be exempted from allegiance to the Mogull their naturall Lord

${ }^{39}$ Ibid., pp. 131-33.

${ }^{40}$ Letter from the Mayor's Court to President and Governor in Council, Fort William, in ibid., pp. 133-135.

${ }^{41}$ Holwell to Council, 16 June 1755 , ibid., pp. $135^{-1} 43$. 
any more than a British subject is freed from his Allegiance to the King of England by embracing the Mahomedan faith .... ${ }^{42}$

In his opinion, therefore, 'Fringys' should be considered natives, since their biological features ('black') and political status (i.e. not 'proper subjects of Portugal') connected them inextricably with the Hindus and Muslims they had 'sprung' from. Since the Hindus and Muslims, as 'natives' of India were exclusively subject to Mughal law (represented, in this case by Holwell himself), the Mayor, dispensing British law, could have no jurisdiction over those identified as 'natives', as Sarah and Phoebe were. It appeared that only their religion (Christianity) required argument: and for this purpose Holwell generated the analogy between Mughal and British sovereignty, neither of which could be overridden by changing one's religion. Of course, nobody had changed their religion in this case, but for Holwell it was essential to use the concept of conversion to explain away the unwieldy qualities of the litigants, and put them firmly in their place as 'natives'.

Holwell also asserted that unless his jurisdiction was affirmed, the functions of the zamindar could not be performed, ${ }^{43}$ an assertion that pointed to the centrality of classification to the working of AngloIndian law. The explosion of uncertainty in classificatory categories did not however lead to the loss of confidence that such categories could be devised. In this case, the Council gave out the amazingly simplistic decision that the zamindar should avoid cases involving 'Fringies' as well as Europeans, unless requested to act as arbitrator. If this was an effort to mop up the disruptive few by using a binary racial scheme (native versus Fringy-European), such classification undermined itself by the associated instruction referring to religious qualifications: a quorum of three judges had to be present to hear criminal cases involving Christians. ${ }^{44}$

Very soon afterwards, the judicial landscape of Bengal was destined to change. The young Nawab of Bengal invaded Calcutta the next year, leading to the Battle of Plassey in 1757 and to the de facto acquisition of political power in Bengal by the East India Company. ${ }^{45}$ Before considering the changes wrought by this 'revolution', the cases

${ }^{42}$ Ibid., p. $13^{6 .}$

${ }^{43}$ Ibid., p. 142.

${ }^{44}$ Charles Fawcett, The First Century, pp. 208-209.

${ }^{45}$ For a discussion of these events, see P. J. Marshall, Bengal: the British Bridgehead (Cambridge: Cambridge University Press, 1987), pp. 70-92. 
discussed above can be used to examine some of the early problems faced by the British in their effort to accommodate the problem of difference in law. A crucial imperative, one that lay behind the abstruse discussions regarding natural law or the varieties of creole populations in India, was the need to distinguish the realm of British law from inherently different forms of law, and as a corollary to that, the British from those who were considered appropriate subjects of different laws. While it appeared that the effort at this stage was to contain difference by separating tribunals and jurisdictions, this approach was inherently unstable.

The elusive goal of a universal law was already being recommended, and perhaps it was prescient of the future that even before the acquisition of political power, the Mayor's Court of Calcutta failed to recognize alternative sovereign sources of judicial power within a single territory. But one should be wary of perceiving a linear progression of legal and judicial centralisation from this point, for in spite of the self-aggrandizing ambitions of a few amateur judges, it was not a simple proposition to arrive at a 'universal law' which transcended the exotic differences of India. Among other things, the Mayors had to contend with British opponents, committed to the recognition of distinct legal jurisdictions in India, and capable of deploying the 'universalising' language of natural law to completely different ends. In Zanocky's case, when the Mayor of Bombay used natural law to assert the apparently 'universal' claims of parents which should be protected by the state, regardless of religious difference, the Governor's response was to point out that this 'universal' right in natural law did not preclude its limitation by customs which may appear exotic to the jurist, but which merely helped the natural lawyer realize the particularity of the laws with which he was familiar. If such customs were recognized by the sovereign, they were the law-an approach that derived from a British common law tradition, which in any case, was informed by natural law theories. ${ }^{46}$

In Phoebe and Sarah's case, the dispute was not about the content of law, but about classifying people to whom different laws and tribunals should apply. In this taxonomic effort, religion mingled with references to embodied characteristics, and tautologically, to political status. Claiming British subject status as a Christian proved problematic for

${ }^{46}$ An old scholarly piece on the role of natural law in shaping common law is Richard O'Sullivan, 'Natural Law and Common Law' in Transactions of the Grotius Society, Vol. $3^{1}$ (1945), pp. $117-13^{8 .}$ 
Sarah with her dark skin and complicated personal and family history. The term 'British subject' was primarily intended as a distinction from 'native' but the distinction was blurred with the presence of Europeans and descendants of Europeans who were (unequal) subjects of other European kingdoms (such as Portugal), or even of the Mughal empire. In the periods that followed, growing assumption of political and legislative power by the East India Company, and later by the British Parliament, helped expand these conundrums into the persistent legal puzzles about difference and universality. In the early-eighteenth century, Christians had the distinction of provoking conflicts that revealed the inadequacy of intellectual and legal axioms underlying the system of personal laws.

Discussing the arbitrary nature of British legal classifications should not, however, obscure an outstanding feature of these cases, which is the active role of Indians, particularly women, in perceiving and exploiting the potential derived from multiple legal statuses and multiple jurisdictions. In discussions of later disputes, scholars have pointed to the utilization of a stereotype of the vulnerable Oriental woman by the British judges keen on overriding multiple legal jurisdictions to offer succour to such potential victims. ${ }^{47}$ Perhaps Indian women were aware of the potential of such a 'sympathetic' audience. Certainly they were active protagonists in choosing legal status, and hence jurisdiction, which would serve their interests. Zanocky perceived that the Mayor's Court was more likely to support her than a caste council, as did Sarah. On the other hand, a pursuit of feminine interests did not necessarily coincide with an attraction for universalizing interpretations of European law, since Phoebe, with her light skin and European husband, felt that the zamindar's court and the status of a native would serve her best.

One can also already see the role of collective petitioning, and cannot but be impressed with the speed with which Indians organized and represented themselves in terms intelligible to the British. The 'tailor' caste in Bombay had obviously impressed the Governor that theirs was a custom that was part of a distinct realm of law whose overarching framework was Hindu, and hence distinct from British law, and they did this within days of Bendu receiving an unfavourable judgement in the Mayor's Court. Such claims, filtered through British legal ideas derived from natural law as well as common law, paved

${ }^{47}$ See Robert Travers, Ideology and Empire, pp. 191-200. 
the way for a system of centralised state-dependent legal pluralism, in which universality remained an elusive but constant quest.

\section{Post-1765: the grant of diwani and the creation of personal laws}

Most scholars consider that the system of personal laws, as we know it today, was inaugurated in $1772 .{ }^{48}$ Important developments had certainly taken place in the years preceding this supposed originary moment. In 1757, the Nawab of Bengal had been defeated in battle by the East India Company, leading to a couple of puppet regimes. This was followed by a further confrontation in 1765 , in which the Mughal emperor himself was involved, and was 'convinced', on defeat, to delegate to the Company the responsibility for the diwani of Bengal, Bihar and Orissa (revenue department and civil justice). ${ }^{49}$ After a period of working through the existing Indian administrative structure, the unsatisfactory revenue yields produced by the de facto administrator, Muhammad Reza Khan ${ }^{50}$ coupled with severe famine and social dislocation, led to the Directors of the Company appointing Warren Hastings as Governor of Bengal in 1772, with orders to arrange for the Company to 'stand forth' as diwan. ${ }^{51}$

This meant new and comprehensive arrangements for the collection of revenue and administration of justice, and Hastings, who claimed to be restoring the 'ancient Mogul constitution' following decades of dislocation, proposed a hierarchical system of courts divided into civil and criminal, or diwani and nizamat, appeals going from the district up to the highest tribunal at the Sadr Diwani Adalat, located at Calcutta, and the Sadr Nizamat Adalat, located at Murshidabad (later Calcutta). ${ }^{52}$ While these courts were to be in theory Mughal

${ }^{48}$ See Derrett's comments on the 'peculiar' provisions of Hastings' plan, the limited set of topics on which shastra was supposed to provide sources of law, and his speculations on why this particular set of topics was chosen over others. J. D. M. Derrett, Religion, Law and the State in India, pp. 233-234.

${ }^{49}$ Peter J. Marshall, Bengal: the British Bridgehead, p. 93.

${ }^{50}$ On Reza Khan's career, see Abdul Majed Khan, The Transition in Bengal I756I 775: a Study of Muhammad Reza Khan (Cambridge: Cambridge University Press, 1969).

${ }^{51}$ Penderel Moon, Warren Hastings and British India (London: Hodder \& Stoughton, 1947), pp. 70-85.

${ }^{52}$ Nizamat (involving military rule as well as criminal jurisdiction) was in theory not the province of the Company as diwan, but of the Nawab, whose capital remained at Murshidabad. Very soon however, the Company did take over complete political power, as well as control over the nizamat adalats, such that Muslim law officers were 
courts, the sources of law were far from clear. As far as civil law was concerned, Hastings suggested in the diwani courts 'all cases of inheritance, marriage or other matters for which Mahomedan law has made a provision should be decided by the established magistrate with the assistance of the expounders of law', and similarly 'that all matters respecting inheritance and the particular laws and usages of the casts of Gentoos should be decided by the established magistrate assisted by Bramins and the other heads of Casts according to Gentoo law' ${ }^{53}$ Reza Khan, trained in Mughal administration, found the idea preposterous: 'to order a magistrate of the faith to decide in conjunction with a Bramin [sic] would be repugnant to the rules of the faith...', he complained. ${ }^{54}$ The day of Reza Khan was coming to an end: arrested for malgovernance in April 1 772, his efforts to train the British in the art of Mughal government were doomed. ${ }^{55}$

In British opinion, their policy was both a continuation of Mughal practice, and a measure of their liberal attitudes, which on several future occasions they could contrast with that of Reza Khan, who developed a posthumous reputation as the archetypical Muslim tyrant. As Robert Travers has pointed out, underlying British assertions of liberalism was a different notion of sovereignty and justice: while the Mughal approach was to countenance the diffusion of adjudication at various social levels; the British one was essentially state-centred. ${ }^{56}$ In other words, Mughal statesmen were willing to make the use of state

relegated to advisory capacity in 1791 . See M. P. Jain, Outlines of Indian Legal History, pp. 58-66, $118-144$. For change in the substance of criminal law, see Radhika Singha, A Despotism of Law, pp. 1-32.

${ }^{53}$ Fort William Letter of 13 April 1 772, quoted in Abdul Majed Khan, The Transition in Bengal, pp. 270-271.

${ }^{54}$ Reza Khan's statement, 4 May 1772, quoted in ibid., p. 271. Unfortunately, information is inadequate regarding the experience of non-Muslims in the pre-colonial Mughal courts. If Mughal practice was at all similar to that of the Ottomans, Mughal qazis would have applied Islamic law to all who chose to submit their matrimonial and inheritance disputes to their courts, otherwise they did not interfere in the intracommunity resolution of disputes. Najwa al-Qattan, 'Dhimmis in the Muslim Court: Legal Autonomy and Religious Discrimination' in International Journal of Middle East Studies, Vol. 31, No. 3 (August, 1999), pp. 429-444.

${ }_{55}$ Chris Bayly has argued that the Mughal administrative elite attempted, in the early days of British colonial rule in India, not only to transfer their skills to the new rulers, but also 'to instruct the British in good government', referring in particular to Muhammad Reza Khan, and his protégé, Ali Ibrahim Khan, who later became the chief judge of Benares. C.A. Bayly, Empire and Information: Intelligence Gathering and Social Communication in India, I $780-1870$ (Cambridge: Cambridge University Press, 1999), pp. 80-83.

${ }_{56}$ Robert Travers, Ideology and Empire, pp. $118-123$. 
courts voluntary for a wide range of social disputes, in particular for family and inheritance disputes of non-Muslims, but once approached the qazi applied a unified law which was, at least in theory, derived from Islam.

In a sense, the approach of the Mayors as well as the Councils in early eighteenth-century British settlements, was similar to that of the Mughal qazis, in that all three conceived of a jurisdictionally limited role for themselves. There were however two distinctions that would lead to a different post-Mughal legal history for India. Firstly, the effort in both British forums to incorporate 'local custom' within a unified legal system and dispense it through a common judicial mechanism, something Reza Khan declared improper for a Muslim judge to do officially. Secondly, and more crucially, as modern nationstates of Europe, including Britain, took shape, they claimed the constitution of the family as their exclusive remit, and from the lateeighteenth century onwards, this led to state-centric, homogenous and exponentially more penetrative regimes of marriage, divorce, child custody, and inheritance laws. As a result, difference, when acknowledged in imperial law, was equally penetrative. The emerging colonial state claimed the right to adjudicate all domestic and property disputes, if according to separate sets of laws, which were valid only if recognized by itself, and which were to be applied according to the legal status of the party, again, determined according to the state's 'objective' criteria. This was indeed a moment of intellectual as well as institutional transformation in Indian law, from which arose the quintessentially modern phenomenon of personal laws. ${ }^{57}$

\section{Universal law and religious law: Supreme Courts, natural law and ecclesiastical jurisdiction}

The quest for universal law remained and expanded at the same time as the development of personal laws, especially with the institution

\footnotetext{
57 The above is an argument regarding the nature of the personal laws which is distinct from, but based on the numerous studies that have shown how colonial codification projects aimed at providing substantive Hindu and Muslim laws in effect displaced traditional Indian legal practice and its traditional specialists. For prominent examples of such works of scholarship, see J. D. M. Derrett, Religion, Law and the State in India, pp. 225-320; Michael R. Anderson, 'Islamic Law and the Colonial Encounter' in Peter Robb and David Arnold (eds), Institutions and Ideologies: a SOAS South Asia Reader (Richmond: Curzon, 1993), pp. $165^{-18} 5_{5}$.
} 
of the Supreme Court at Calcutta in 1774 , by order of the British Parliament, as successor to, and superseding, the Mayors' Courts. The Supreme Court's jurisdiction was ab initio limited: 'racially' its authority extended over all British subjects in the province, territorially over all persons within the city of Calcutta, and more expansively, over all persons employed by the Company or its servants. In more than one way therefore, a territorial division of the capital from the country, the former run by British law and the latter by Company-as-Mughal law, was subject to tensions due to overlap. Scholars, including Robert Travers, have also discussed how the Supreme Court judges used transcendent claims, premised once again on 'natural law', to exercise judicial review over the functioning of the Company's Courts. ${ }^{58}$ But it would be widely inaccurate to imagine that the Company's Courts were pure 'Mughal courts' (any more than Holwell's zamindari had been); other than completely un-Mughal notions of religious civil law, these courts were manned by British officials, and regulated by rules framed by the British government at Calcutta, whose state imperatives led to a complete transformation in criminal law. ${ }^{59}$

The Supreme Court's references to natural law, which was in the end a philosophical principle, has received attention from scholars who see within such arguments the British tendency to push back the claims of indigenous laws and indigenous legal specialists. There was another more substantive aspect of the Supreme Courts which has received little attention, which is that other than civil, criminal, equity, and admiralty, it possessed a jurisdiction known as 'ecclesiastical'. Although derived from 'ecclesia' or the Church, the ecclesiastical law of Britain was, especially since the Restoration, canon law as recognized by the state, and dispensed by state courts, even if these courts were manned by clerics. Until 1857 ecclesiastical jurisdiction,

\footnotetext{
${ }^{58}$ Robert Travers, Ideology and Empire, pp. 181-206. The case discussed was one of a Muslim widow who claimed entire possession of her husband's estate on the basis of a will, as opposed to the claims of the husband's nephew as the principal male successor. Defeated in the provincial diwani adalat when the qazi and mufti, the Muslim law officers, decreed against her and even evicted her, she proceeded to Calcutta to file her case in the Supreme Court in 1778 , which found in her favour in 1779 and indicted the provincial administration for illegitimately delegating their judicial duties to the Muslim law officers, and for victimizing a helpless Asiatic woman.

${ }^{59}$ One of these imperatives was more summary methods for dealing with 'law and order' problems, such as 'Thagi', which led to framing homicide as murder rather than as a negotiable civil cause, as in Islamic law. See Radhika Singha, A Despotism of Law, pp. 1-32.
} 
under English law, included all matrimonial and custody disputes, and a substantial section of inheritance causes, particularly those involving wills on large estates. ${ }^{60}$ In the colonies, because of the absence of an adequate Anglican establishment, the higher crown courts often possessed an ecclesiastical side. ${ }^{61}$ The colonial distinction was the limitation of jurisdiction: the Calcutta Supreme Court's ecclesiastical jurisdiction was expressly limited to all British subjects (as opposed to 'natives') in the province, and the relevant law was to be the ecclesiastical law used in the diocese of London. ${ }^{62}$ The Company courts being, in theory, Mughal courts, did not possess ecclesiastical jurisdiction, and in any case had no jurisdiction over Europeans. Hence when they dealt with matrimonial and inheritance disputes, they expected to apply either Muslim or Hindu law, depending on the status of the parties. Problems arose when certain parties failed to meet these identifying criteria precisely enough, producing not even a conflict of jurisdiction, but a seeming lack of it.

In 1839 , two Parsi ${ }^{63}$ young men, Dhanjibhai and Hormasji, converted to Christianity under the guidance of the Scottish missionary John Wilson. Both took refuge in the missionary's house and while legal claims for Dhanjibhai's custody by his guardians failed, ${ }^{64}$ his married friend Hormasji entered a protracted legal battle with his natal family and that of his Parsi wife, who all treated his conversion as the end of his claims on his family. A month after his baptism, Hormasji's daughter was affianced without his consent. Although Hormasji did not resist this directly, he kept up his efforts to recover his wife and

${ }^{60}$ In fact, the English law of marriage was canon law, as modified by certain statutes, such as Lord Hardwicke's Act of 1753 . R. H. Helmholz, Marriage Litigation in Medieval England (London, 1974), p. 3; J. H. Baker, An introduction to English legal history ( $^{\text {rd }}$ edn, London, 1990), pp. 567-568; Lawrence Stone, Road to divorce: England 1530-1987 (Oxford, 1990), pp. 353-390. On the changing jurisdiction over inheritance causes, Lloyd Bonfield, 'Testamentary Causes in the Prerogative Court of Canterbury, 166o96' in Christopher Brooks and Michel Lobban (eds), Communities and Courts in Britain, I I 50- I 900 (London: Hambledon Press, 1997), pp. 133-154.

61 This was true of India, as well as in the Straits Settlements.

62 'Letters Patent establishing the Supreme Court at Fort William, 1774', in Anil Chandra Banerjee, Indian Constitutional Documents I 757-I947 (4 $4^{\text {th }}$ edn, 4 vols., Calcutta: A. Mukherjee \& Co., 1974), pp. $3^{6-43}$. Similar courts were set up in Madras in 1800 and Bombay in 1823 .

${ }^{63}$ Zoroastrians who migrated from Iran to India in the seventh century, and settled in rural Gujarat, later moving into Bombay as commercial entrepreneurs.

${ }^{64}$ On the grounds that, at sixteen, when most Parsis were married, he should be considered an adult. 'Conversion of two Parsis, and prosecution of the Rev. John Wilson, D.D., on a writ of habeas corpus, before the Supreme Court of Judicature at Bombay. Crown side', Oriental Christian Spectator (June, 1939), pp. 209-291. 
daughter, and only in 1843 , after his wife had married another Parsi man, he applied to the Bombay Supreme Court to regain custody of his daughter. The Court's discussion preceding the judgement was remarkably similar to the one occasioned by the Zanocky case in June 1730 mentioned above. It turned on the question of whether the natural law right of the father to custody of his children ${ }^{65}$ could be shown to have been superseded in this case by the existence of a Parsi law directing loss of custody on religious conversion. Since no such law could be found, Hormasji received custody of his daughter, ${ }^{66}$ but recovering his wife appeared out of the question.

In the same year, a deserted Parsi wife attempted to recover her husband, or at least, his obligations towards her, by instituting a case for the restitution of conjugal rights on the ecclesiastical side of the Supreme Court of Bombay. The husband, who was acting in defiance of the Parsi panchayat or body of elders ${ }^{67}$ argued that since he was a Zoroastrian, the court had no jurisdiction over him in the matter. Although Justice Erskine Perry ruled that it did, the husband remained recalcitrant, and in $185^{6}$, a further attempt by the wife was dismissed by the Privy Council on the grounds that ecclesiastical jurisdiction did not apply to the Zoroastrian marriage. ${ }^{68}$

The cases involving the Parsis, a community undergoing rapid religious and social change in the nineteenth century, including conversions to Christianity, reveals important trends of development in the colonial Indian legal system, and how a community that was itself 'exceptional' negotiated and experienced this system. By being neither Hindu nor Muslim, the Parsi collective claim to a discrete body

${ }^{65}$ Veena Das has used the judgement in this case to underline the political construction of paternity, which was presented as a natural state. Zanocky's case warrants reconsidering the conflation of parental right with paternity in British legal thought. Veena Das, 'Secularism and the Argument from Nature', in David Scott and Charles Hirschkind (eds), Powers of the Secular Modern: Talal Asad and His Interlocutors (Stanford: Stanford University Press, 2006), pp. 93-112.

${ }_{66}$ The Queen v. Shapurji Bezonji and Bezanji Edalji, 28 February 1843 , Indian Decisions (Old Series) (Madras: T.A. Venkasawmy Row, 1912), Vol. 4, pp. 84-94.

${ }^{67}$ On the creation of the Parsi panchayat as a 'traditional' judicial body under British patronage, see Susan Stiles Maneck, The Death of Ahriman: Culture, Identity and Theological Change among the Parsis of India (Bombay: K.R. Cama Oriental Institute, 1997), pp. 160-181. The panchayat was opposed to bigamy, but a nouveau-riche faction within the community, represented by young men such as Ardasir, were defiant of this rule because they wished to establish a more companionate second marriage for themselves, being dissatisfied with their uneducated first wives, usually married in childhood. On the Ardasir case, Ibid., pp. 173-175.

${ }^{68}$ Ardaseer Cursetjee v. Perozeboye, (1856) Moore's Indian Appeals, 348-392. 
of law was weak, hence a young man (Dhanjibhai) deemed adult was not deprived of his physical and religious freedom for disobeying his guardians and changing his religion. Also, a Parsi father (Hormasji) was able to recover custody of his child in spite of changing his religion, in the absence of a recognized law to the contrary. In the case of marital obligations however, it appeared that difference overrode any possible universality. Each of these episodes alerted Parsis to the strength of the British legal system, and the need to discover a coherent body of personal laws, to prevent being subjected to English ecclesiastical laws, or the projected 'uniform civil code', which, in the absence of special 'exemptions' (as already in place for Hindus and Muslims) appeared to be on the verge of imposing a British law that claimed to be indifferent to religion on all residual categories. The Parsis organized themselves with tremendous alacrity, representing effectively to the British government the rules that the Zoroastrian religion prescribed for marriage, divorce, custody and inheritance, ${ }^{69}$ which unsurprisingly included grounds for divorce and disinheritance on the premise of religious out-conversion. ${ }^{70}$

\section{Law Commissions and the debate over the 'lex loci'}

The Parsi project narrowly apprehended, and dovetailed itself into a massive imperial scheme for rationalizing and codifying the laws of

${ }^{69}$ For a comprehensive documentation of this project, see Sorabjee Shapoorjee Bengalee, The Parsi Marriage and Divorce Act 1865 (Bombay: Duftur Ashkara Press, 1868). I am grateful to Mitra Sharafi for this reference, and for alerting me to the dynamic legal history of Parsis in India.

70 The draft prepared by the Parsi Law Association, consisting of modern, legally active Parsi leaders, demanded dissolution of marriage following out-conversion, but this was vetoed by the Select Committee of the Governor-General's Council, presided over by Henry Maine. See papers connected with an Act to define and amend the law relating to marriage and divorce among the Parsees, XV of $186_{5}$, Government of India, Bills and Acts, $\mathrm{L} / \mathrm{PJ} / 5 / 7$, APAC. In the amended Parsi Marriage and Divorce Act, III of 1936, religious change was re-inserted as a ground for seeking divorce, although not for automatic dissolution, since Parsi activists were also concerned with preventing the avoidance of marital duties (including monogamy) by conversion to Hinduism or Islam. Pestanji Phirozshah Balsara (ed.), The Parsi Marriage and Divorce Act, (Bombay: Jehangir B. Karani's Sons, 1936). As for inheritance, Parsi activists appear to have concentrated their energies on barring access to Parsi charitable trust funds (rather than on private estates) for those who did not in their opinion qualify as Parsi. For a path-breaking study of Parsi self-definition in and through the AngloIndian legal system, and the rise of race in the early twentieth-century, see Mitra June Sharafi, 'Bella's case: Parsi identity and the law in colonial Rangoon, Bombay and London, 1887-1925' (unpublished Ph.D. thesis, University of Princeton, 2006). 
India. On the occasion of the Company's charter being renewed in 1833, the British Parliament examined the state of government in India, and the legal situation was found particularly unsatisfactory. A number of British judges who had worked in India complained of the conflicting jurisdictions and conflicts of law endemic in the system. With the Charter Act of 1833 , the British Parliament decided to add a specialized law member to the Governor- General of India's Council, this office being occupied by Thomas Babington, Lord Macaulay. In 1835, Macaulay was also appointed chair of the First Indian Law Commission, which was to investigate the situation of Indian laws, and propose improvements. ${ }^{71}$

Among the relatively minor issues with which the first Commission dealt were the petitions of the East Indians ${ }^{72}$ and Armenians complaining that there was no adequate law securing the validity of their marriages and inheritance practices. In 1842 , the first Law Commission rejected an existing government proposal for a specific law regulating the marriages of East Indians, on grounds that this racial category was too indefinite, a declaration that would have won the approval of Holwell, if not the recommendation that flowed from it. In the Commissioners' opinion, the East Indians would best be served by one uniform law for all those who were not Hindus or Muslims, which should be the lex loci, or 'law of the country'. This then led to discussion of what the lex loci was or ought to be, a discussion also relevant in determining the validity of legislative interventions in matters of pan-imperial significance, such as the abolition of Indian forms of slavery. ${ }^{73}$ On this occasion, the law commissioners considered, perhaps for the last time, the possibility that Muslim law was the lex loci of India. This reprehensible possibility was however rejected by resurrecting the long-buried Reza Khan, using his condemnation of the personal law system as evidence of the inability of Muslim law to restrict itself, and hence being sufficiently tolerant to difference, as only English law could. ${ }^{74}$

${ }^{71}$ M. P. Jain, Outlines of Indian Legal History, pp. 405-414. There still needs to be written a sufficiently nuanced and comprehensive ideological and institutional history of the Law Commissions. For a useful discussion focussed on criminal law, see Elizabeth Kolsky, 'Codification and the Rule of Colonial Difference'.

72 Anglo-Indians.

${ }^{73}$ Copies of the Special Reports of the Indian Law Commissioners, Parliamentary Papers, House of Commons (henceforth PP) 1842, (585) XXX, pp. 227-866, V'Power of a master over his slave'.

74 'On the petitions of the East Indians and Armenians, B VIII, ibid., p. 671. 
Even if this declaration was made, it still remained unclear, given that the supremely tolerant English legal system had undertaken to dispense Muslim and Hindu law, what rights accrued to a person when the Hindu or Muslim laws appeared to indict him or her, for offences particular to those laws. Was there an area of civility outside religion? In 1830 , Governor-General William Bentinck, with instructions from the Court of Directors, was determined to establish that there was, especially where the civil rights of Indian converts to Christianity were concerned. ${ }^{75}$ To this end, he legislated Regulation VII of 1832 of the Bengal Code, of which Section IX provided:

in any civil suit, the parties to such suit may be of different persuasions, when one party shall be of the Hindoo, and the other of the Mahomedan persuasion, or where one or more parties to the suit shall not be either of the Mahomedan or Hindoo persuasions, the law of those religions shall not be permitted to operate to deprive such party or parties of any property to which, but for the operation of such laws, they would have been entitled. ${ }^{76}$

If this had any effect in Bengal, it obviously had none in other Presidencies, where it did not apply. But an evangelical Anglican Bishop of Bombay thought the form of the law worth pursuing, and hence, between 1845 and 1849 , Reverend Thomas Carr, repeatedly wrote to the Government of Bombay, remonstrating against the British government's failure to protect converts to Christianity from loss of civil rights, and especially from being disinherited. He proposed that the Bengal Regulation be extended to all parts of India. ${ }^{77}$ When the then current law member, J.D. Bethune, considered such a possibility, he wondered whether it would be valid to prescribe automatic transfer of property whose inheritance was tied to certain conditions. Conditional bequests and entailed estates were well known in English law, and it could be argued that Hindu inheritance was similarly dependant upon the fulfilment of certain conditions, among them the performance of funerary rites for the deceased, a function which the convert was incapable of fulfilling due to loss of caste. ${ }^{78}$ But the Bengal Regulation seemed to have already severed the connection

75 The Vice-President in Council to the Court of Directors, Letter 393, 3 January 1832, in C. H. Philips (ed.), The Correspondence of Lord William Cavendish Bentinck, II: $74_{76}^{8-75^{1 .}}$

76 'Regulations passed by Governments of Bengal, Fort-St.-George and Bombay, $1832^{\prime}, P P, 1833$ (755) XXV, pp. 352-353.

77 Letter from Bishop of Bombay to Governor of Bombay, 28 March 1849, India Legislative Consultations, 11 April $185^{\circ}$, no. 57 (unpaginated), P/207/59, APAC.

${ }^{78}$ Minutes of members of Council, Ibid., no. 59 . 
between Hindu doctrine and inheritance-or had it? When consulted, the judges of Calcutta's Sadr Diwani Adalat ${ }^{79}$ stated that they knew of no cases being argued under the Bengal Regulation, and the Sadr Diwani Adalat of the North-West Provinces could only refer to one case of which they provided no details. ${ }^{80}$

Meanwhile, government received volumes of angry criticism from the Hindus of Calcutta and Madras. The conservative Hindu leader Radhakanta Deb stated that the Bengal Regulation had been completely unknown to him, and that the law was an invasion of Hindu laws of inheritance. Strongly reacting to the suggestion that they were being as intolerant, Deb and his co-petitioners argued that Hindus were the most tolerant of people since they had little interest in proselytization. All they asked for was protection of their own rules of inheritance, which was a religious matter, and long recognized by the government. ${ }^{81}$

This particular debate was crucial enough to extend right up to the British Parliament, with the Conservative M.P. Lord Ellenborough, ex-Governor-General of India, representing the Hindu conservative view, also adding the more palatable and comprehensible (to a British audience) gloss that Hindu inheritance laws helped to exclude immoral persons from familial estates. ${ }^{82}$ One person who took great offence at such insinuation was a Bengali Hindu teacher, who had converted to Christianity in 1832 , suffered greatly in his personal and professional life as a result, and later been ordained with Anglican orders. ${ }^{83}$ Reverend Krishna Mohan Banerjea argued that it was a simple matter of conflict of laws, in which, by established rules, the laws of the defendant were to be used. Since the Christian convert was likely to be the defendant against his or her relatives, it was Christian personal law that ought to be applied. ${ }^{84}$ Radhakanta Deb, who had

${ }^{79}$ Highest civil 'Company' court in a province.

${ }^{80}$ Ibid., Nos 61-64.

81 The Memorial of the Hindoo Inhabitants of Bengal, Behar and Orissa to the Governor-General of India in Council against the Proposed Act for altering the Hindoo Law of Inheritance (Calcutta: Englishman Press, 1850), printed pamphlet, Ibid., no. 80 .

${ }^{82}$ K. M. Banerjea, Remarks on the Speech of the Earl of Ellenborough in the House of Lords, on the Bengal Petition against Act XXI of I 850 of the Government of India (Calcutta: R.C. Lepage \& Co., 1853), pp. 3-6. Banerjea summarized Ellenborough's speech before making his comments.

${ }^{83}$ Ramachandra Ghosha, A Biographical Sketch of the Rev. K.M. Banerjea: Missionary, Scholar, Patriot ( $2^{\text {nd }}$ edn, Calcutta, 1980), pp. 14-22.

${ }^{84}$ K. M. Banerjea, Remarks on the Speech of the Earl of Ellenborough, p. 14. 
been a patron of Krishna Mohan in his pre-Christian youth, and had since become a vicious enemy, spat back the crucial question: what personal laws did Christians in India have? ${ }^{85}$

Radha Kanta Deb had located the crux of the problem: there was no Christian personal law, and Indian Christians, particularly those who had converted to Christianity, were located in an indeterminate zone by being excluded from the realms of Hindu, Muslim or the (emerging) Parsi laws by their religion, and from automatic entry into English law by their race. If Hindu law was to apply to Hindus alone, and if inheritable property devolved (among Indians) by religious law, then what law applied to the Indian who had ceased to be Hindu, or Muslim, or Parsi? Lord Dalhousie's Government declared that the state had complete authority to control succession to property, Act XXI of $185^{\circ}$ declaring that 'no person would suffer loss of rights he otherwise possessed because of a loss of caste'. ${ }^{86}$ The consequences of this declaration were more complex than most historians have realized. It certainly did not imply an uncomplicated assertion of the sovereign right to regulate the transfer of property and responsibility to protect against civil injury for religious belief. ${ }^{87}$ But neither was this declaration of universal intent completely hollowed by state imperatives to retain ascriptive status in law in general ${ }^{88}$ or, in particular, its need to protect the Hindu social order. ${ }^{89}$ While there were indeed powerful Indian voices seeking the ear and arm of the colonial regime to sustain, or (as Washbrook has suggested) create 'traditional' social orders, there remained the search for the universal, which, however muted, added a dynamic to the system. The historical role of the Indian Christians was not just to expose the hollowness of the unsubstantiated universal, but also to incite a quest for making it more substantive.

The declaration of lex loci by Act XXI of $185^{\circ}$ did not, in spite of all its bluster, provide clear answers to the questions raised in debates

85 A Reply to K.M. Banerjea's Remarks on the Speech of the Earl of Ellenborough in the House of Lords delivered on the $26^{\text {th }}$ of May ${ }_{1} 853$ against the Act XXI of I 850 of the Government of India. By a Member of the Committee appointed by the Hindu inhabitants of Bengal, Behar and Orissa, for Petitioning Parliament against the aforesaid Act. (Calcutta, P.S. D'Rozario and Co., 1853 ).

${ }^{86}$ India Legislative Consultations, 9 April 185 o, No. 86.

87 Thomas Metcalf, Aftermath of Revolt, pp. 27-28.

${ }^{88}$ Even if these statuses were themselves the product of evolving political and social relations, as Washbrook argued in his 'Law, State and Agrarian Society'.

${ }^{89}$ Chandra Mallampalli, Christians and Public Life, pp. 21-37. 
between Bengali Christians and Bengali Hindus in the years preceding the legislation. In effect, Act XXI was a negative law, prohibiting discrimination, not providing a rule for regulating inheritance where religious status was in dispute. Ironically, the inconclusiveness of such a legal declaration is demonstrated in the case related below which involved no 'converts', but only a warring family that was entirely Christian.

\section{Could Christians be Hindus if they wanted to? Abraham versus Abraham, 1863}

The case of Abraham versus Abraham was in many senses representative of a wide range of Indian society, and not Christians alone. It involved familial conflicts over property following the death of a male member, including efforts by surviving male relatives to exclude the widow and children of the deceased, and the use of competing claims based around religious status. But the distinctive feature of this case was that all parties belonged formally to the same religion: Christianity. The case revealed how certain individuals within the highly diverse social group of Indian Christians adeptly manipulated their multiple affiliations, as well as the increasingly dominant equation of Christians with converts, in order to maximize their individual benefits. In a more abstract sense, the case showed that declaring non-discrimination on religious grounds as the lex loci did not help close the continuing conflict between difference and universality, but added further conduits for passage between both legal ideas.

The case itself was a sordid one involving efforts by the brother of a dead man to deprive the latter's widow and sons of any benefit from his substantial property. In 1855 , Charlotte Abraham, widow of Matthew, complained in the Civil Court of Bellary, in present day Karnataka, that Francis Abraham, the surviving brother, a junior partner in the business during Abraham's lifetime, and subsequently the de facto manager, was depriving her and her sons of property and profits related to her husband's business. Francis retorted that since his family were descendants of Hindus, Matthew Abraham's property devolved upon him by Hindu inheritance laws of joint family property, the widow being entitled merely to maintenance. The main point to be decided during the judicial proceedings was the applicable law. It was clear that being Christian did not entail any particular law as far as property was concerned, therefore, Hindu law could be applied 
if the family appeared to be Hindu in practice. The Bellary Civil Judge's decision denied Francis's claims, which was reversed by the Sadr Diwani Adalat of Madras, and overturned again by the Privy Council. The highest judicial body of the British empire decided in 1863 that Matthew, on marrying Charlotte, who was 'East Indian' had adopted 'East Indian' customs, which were similar to those of the English ${ }^{90}$ and hence revealed no inclination to retain Hindu customs, even though he might have done so. ${ }^{91}$

This case has received attention from two scholars in recent times, but unlike them, I have not found this case an occasion to celebrate open-ended constructions of Indian Christian identity without reference to their gendered implications, ${ }^{92}$ nor to discover arbitrary manipulation of religious or racial identities by the British government. ${ }^{93}$ I find the case symptomatic of the categorical disjunction at which Indian Christians were located, which allowed the combination of the universalist premise of the lex loci and the trope of the 'convert' for patriarchal interests. But this was not the end of the story.

\section{The Indian Succession Act, $186_{5}$}

The Abraham case remained valid precedent for less than two years. While the law lords discussed the status of the people in the Abraham family, the third Law Commission of India was working (in Britain) on an Indian Civil Code, with the law member, Henry Maine, leading the efforts in India. Unlike the Penal Code, promulgated in 1860, the Civil Code of India was never completed, with the fourth and last commission declaring that it was a matter that depended on the will of the 'native communities' themselves. ${ }^{94}$ What remained

90 After much petitioning, and several reversals, rather than through a simple assumption of racial similarity. The Vice-President in Council to the Court of Directors, Letter 393, 3 January 1832, in C. H. Philips (ed.), The Correspondence of Lord William Cavendish Bentinck, pp. 748-751; Memorial of the Undersigned Christian Inhabitants of the Presidencies of Bengal and Agra, Chiefly Descended from British-born Subjects of the Crown on the Father's Side and on the Mother's from Natives of India; also of the Christian Foreigners, and their Descendants, Settled in the British Possessions in India, now Governed by the East India Company (Calcutta, $185^{\circ}$ ).

${ }_{91}^{11}$ Abraham v. Abraham, Moore's India Appeals, Vol. 9 (1863), pp.195-255.

${ }^{92}$ Chandra Mallampalli, Christians and Public Life, pp. $3^{8-} 5^{8 .}$

93 Gauri Viswanathan, Outside the Fold, pp. $111-117$.

${ }^{94}$ Report of the Indian Law Commission, I 879 (Calcutta, 1880), pp. 9-1 8. 
of this old 'uniform civil code' project was a unified judicial system, abolishing the conflicting jurisdictions of the Company and Crown Courts, a law of Civil Procedure, and certain laws bearing the proud title 'Indian', recalling the (failed) agenda of universalism from which they were born. One such law was the Indian Succession Act X of 1865 which, on the face of it, purported to be a uniform inheritance law for India. In reality, the law applied to very few Indians, since Hindus and Muslims were totally exempted from its provisions, and Parsis from the provisions of intestate succession. ${ }^{95}$ Given these exemptions, the law applied to those whose indeterminate legal status had often in the past invoked the search for the universal, namely the Indian Christians. ${ }^{96}$

The government of India did investigate whether the law could be applied to all Indians, seeking the opinion of prominent Indians from all over the country. ${ }^{97}$ Parsis, who had been collectively working on their own marriage and inheritance laws, accepted the section on wills only. ${ }^{98}$ Prominent Muslim leaders, including none less than Sayyid Ahmad Khan, rejected the law entirely, on the basis that the rules of Muslim intestate succession were known, and that their own laws regarding wills limited testamentary capacity to one-third of the estate, in absence of the unanimous consent of the ordinary successors. This varied from the total testamentary power contemplated under the Indian Succession Act. In addition, Sayyid Ahmad pointed out that since the Quran recognized oral wills, the Indian Succession Act, which made registration of wills compulsory, would be an invasion of Muslim religious laws. ${ }^{99}$

${ }^{95}$ Act $\mathrm{X}$ of 1865 Indian Succession Act, and connected papers, in India Bills, Objects and Reasons, Part 3, 1865, L/PJ/5/7, APAC.

${ }^{96}$ I do not agree with Mallampalli that the application of this law to Indian Christians revealed the misguided British belief that those who shared their religion would be apt recipients of British law. The process worked in the reverse: the Indian Succession Act aimed to be a universal law, applied to those for whom specific exemptions had not been made.

${ }^{97}$ Government of India Legislative Proceedings, 22 August 1865, No. 41, pp. 924-926, P/208/1 1; Government of India Legislative Proceedings, 8 February 1866 , No. 8, pp. 49-5o, 19 April 1866 , No. 6, pp. $118-143$, P/436/53, APAC.

${ }^{98}$ William Griffith, The Indian Succession Act: Hindu Wills Act, Parsi Succession Act, Mahometan Succession and Probate and Administration Act, with the other Acts and rules regulating the disposition and devolution of property of death and with commentaries thereon and forms used in practice (Madras: Higginbotham \& Co., 1898).

${ }_{99}$ Government of India Legislative Proceedings, 19 April 1 866, No. 6, pp. 1 26-1 28, $\mathrm{P} / 436 / 53$, APAC. 
Hindu respondents similarly did not need to contend with intestate succession, and many argued that Hindu law did not countenance wills, since the share of inheritance was pre-ordained. This was contradicted by the fact that Hindu wills were in evidence aplenty in India from the late-eighteenth century onwards in colonial Indian courts. The law member, Fitzjames Stephen, took this to mean that Hindus had admitted to the non-religious status of wills, and that Hindu wills were a mere derivation from the English example, therefore open to regulation by government. Accordingly, the Hindu Wills Act was passed in 1870 , extending the section on testamentary succession in the Indian Succession Act to them. But in response to pressure from prominent Hindus, including the British Indian Association, the Hindu Wills Act incorporated several additional privileges, such as the ability to divert property to religious and charitable purposes, without the year's notice required by the Indian Succession Act, ${ }^{100}$ which remained a powerful tool in the hands of disgruntled parents.

It was not as if Indian Christians were particularly eager to embrace the succession law modelled on English law, especially since it gave one-third of the male intestate's property to his widow, and equal shares of the residue to daughters and sons, excluding the joint family consisting of male agnates. The Abraham case at least showed that there was a difference of opinion on the subject. But men like Francis Abraham, who would be happy enough to claim the Hindu law of inheritance (especially mitakshara, which excluded females), could not really argue that, as Christians, they possessed an older law of inheritance. The possibility of claiming multiple religious and hence legal statuses (as with Abraham) went against the grain of the personal law system, hence all those for whom specific exemptions were not made were subject to the Indian Succession Act. The irony was that by sheer delimitation, this 'universal law' became a personal

${ }^{100}$ By Section 105 of the Indian Succession Act: 'No man having a nephew or niece or any nearer relative shall have power to bequeath any property to religious or charitable uses, except by a will executed not less than twelve months before his death, and deposited within six months from its execution in some place provided by law for the safe custody of the wills of living persons.' William Griffith, The Indian Succession Act, pp. 67-68. For a record of the efforts of the Government of India to extend a homogenous law of wills to all Indians, and a predictable disintegration of the effort through the preservation of special privileges for and constraints upon Hindu and Muslim testators, see Government of India Legislative Proceedings, August 1870 , Nos $5^{6-111}$, pp. 79-131, P/436/58, APAC. 
law of inheritance for Indian Christians. ${ }^{101}$ Many Christians took this development to be opposed to their interests. The All India Conference of Indian Christians, formed in 1914, complained vociferously that this statute denied them of their full rights under Hindu inheritance laws, in spite of the Lex Loci Act of $185^{\text {o. }}{ }^{102}$

\section{Christian marriage: from a British civil law to a novel personal law, $185^{2}$}

Unlike legislation regarding inheritable property, legislation for Christian marriage in India originated in problems perceived purely as 'British'. However, as soon as the process of legislation was initiated, it was discovered that taking Christian marriage to be entirely within the realm of British domestic life and British law was an unsustainable proposition which conflicted with the complex legal and social reality of India. Dealing with this reality led back to the fraught issue of racial status, as well as the civil rights of those who had converted to Christianity. In spite of government being made aware of these issues, the British Parliament, in providing a coherent marriage law for 'British subjects' in British colonies and abroad, took only tangential note of those Indians who would be affected by it. Once legislated, the Indian (Christian) Marriage Act(s) had such disruptive consequence for Indian Christians that the government was forced to repeatedly legislate in order to 'fix' problems which were of its own creation. In analyzing this process, one is made deeply aware of the limitation of British legal concepts, when religion did not correspond with, but undermined notions of, racial distinctiveness. It also points to the effects of a state-centric regulation of difference, in the context of

101 Many Christians continued to claim access to Hindu inheritance law, as in Tellis versus Saldanha, Indian Law Reports, (1886) 10 Mad. 69-73, where it was denied, and in Francis Ghosal versus Gabri Ghosal, Indian Law Reports (1907) 31 Bombay 25-31, where it was accepted. But it remained applicable for Indian Christians who could not secure express exemption, on the basis of customary practices, such as, among others, the Christians of Coorg, and Punjab. Flavia Agnes, Law and Gender Inequality: the Politics of Women's Rights in India (New Dehi, 1999), pp. 148-14; A.C. Ghose, The Indian Succession Act (Act XXXIX of 1925), (Calcutta: M.C. Sarkar \& Sons, 1926), pp. 11-12.

102 S. C. Mukerji, 'Law regarding Indian Christians' in The Report of the Third Session of the All India Conference of Indian Christians, held in Madras, December I9I6, (Madras, 1917), pp. 40-47, United Theological College Archives, Bangalore. 
totalizing regimes of modern law for which the 'family' was a state concern.

The origin of the problems that led to the first Christian marriage law in India, lay in Britain, and the nature of the British statechurch relationship as it stood in the early nineteenth century. Canon law recognized marriages that were no more than declarations of intent in the present tense, even without the presence of witnesses, but by the sixteenth century, British courts took the view that the presence of a priest in 'holy orders' was essential for the complete validity of a marriage. ${ }^{103}$ Following the scandals involving indiscreet marriages of the wealthy, often performed in secret by 'rogue' priests, Lord Hardwicke's Act of $1753^{104}$ outlawed all marriages not duly celebrated, ministered and registered in an Anglican church or chapel, with five exceptions: the Archbishop's licence, royal marriages, marriages abroad (provided such marriage were celebrated by a law that recognized Christian marriage), marriages between Jews, and those between Quakers. ${ }^{105}$ Although the above law did not apply to Scotland, there arose doubts regarding the validity of marriages performed by ministers of the Scottish church in India, and hence a specific legislation in 1818 permitted such marriages provided such ministers were also chaplains of the East India Company. ${ }^{106}$

This still left a significant number of people 'out in the cold', and these happened to be Nonconformist missionaries, whose deeply held religious views made it unlikely that they would take such an 'establishment' 107 view of religion and marriage lying down. Since they proceeded to exercise what in their view were their ministerial duties, by performing marriages when invited to do so, the (Anglican) Bishop of Calcutta, Daniel Wilson, complained to the GovernorGeneral of India in 1833 that law of marriage had been disturbed by such activities, and that the law should be clearly settled, because it affected 'all the bonds of moral and domestic happiness, spreading

103 This caused certain problems for Jews and Quakers, whose religious tenets did not include priests. H.S. Q. Henriques 'Jewish Marriages and the English Law' in The Jewish Quarterly Review, Vol. 20, No. 3 (April, 19o8), pp. 391-449.

104 An Act for the better prevention of clandestine marriage, 26 Geo. II c. 23 of 1753 .

${ }^{105}$ The Clauses providing the exceptions were 6,17 and 18.

${ }^{106}$ An Act to remove doubts as to the validity of certain marriages had and solemnized within the British territories in India, 1818,58 Geo. III c. 84 .

${ }^{107}$ In the sense of a privileged legal relationship between a particular church and the state, such as the Anglican church in England, and at the time, in Wales and Ireland as well. 
in its consequences to every branch of the social, civil, and religious relations of families, and involving the rights of property and the order of legitimacy and succession.' In the Bishop's view, in natural law, marriage was considered a contract between two individuals even without the intervention of any other party, but to be valid in a civil society, marriage had to be regulated by law, and in a Christian country, it had to be further sanctified by a vow to God. Marriage valid in ecclesiastical law had to consist of all three of these aspectsand such was the law that governed British subjects. Hence, in the Bishop's opinion, the Nonconformist ministers had broken the law, which was deplorable, given that they claimed to be missionaries of religion. ${ }^{108}$

Nonconformist ministers themselves took quite a different view, unsurprisingly, and petitioned the Governor-General for a law that would validate marriages performed by 'Protestant dissenting' ministers, which the Government of India forwarded to the Court of Directors of the East India Company. ${ }^{109}$ At this stage, Bishop Wilson stated sharply that he failed to appreciate the scruples of dissenting ministers, and indeed how was a dissenting minister-his faith, creed and competence-defined? Could a Socinian, denying the Divinity of our Lord, or a mere printer or schoolmaster be counted as a dissenting minister, and stand in the place of a priest in holy orders? ${ }^{110}$

Bishop Wilson, who is known for his Evangelical rather than for his high church views, ${ }^{111}$ took in this case a slightly dated approach to the issue of marriage laws and their establishment: in 1836 in Britain, in response to demands by Nonconformists, a law was enacted permitting civil marriage before a Registrar for those who had conscientious objections to being married in an Anglican church. ${ }^{112}$ Although in

${ }^{108}$ Lord Bishop of Calcutta to the Governor-General, 21 August 1833, in Royal Commission to inquire into State and Operation of Law of Marriages, PP $185^{\circ}$ (1203) XX, pp. 363-430, at pp. 391-395.

${ }^{109}$ Legislative Council, Calcutta, to the Court of Directors, 3 December 1838 , forwarding the petition of the Dissenting Ministers, Nos 6-7, in ibid., pp. 400-401.

${ }^{110}$ Letter from the Bishop of Calcutta to the President in Council, 3o January 1839 , No. ${ }_{15}$, in ibid., pp. 405-40.

${ }^{111}$ For his support of missions to India, in particular to the Church Missionary Society, and his personal enthusiasm for the conversion of Indians, see Josiah Bateman, The Life of the Rt. Rev. Daniel Wilson (2 vols., London, 1860).

112 Marriage Act 1836, 6 \& 7 Will. IV c. 85 . For some indication of Nonconformist politics and Anglican clerical opposition preceding this legislation, see Olive Anderson, 'The Incidence of Civil Marriage in Victorian England and Wales' in Past and Present, 69 (November 1975), pp. $5^{\mathrm{o}-87}$. 
the Bishop's opinion, this law was a failure, a Special Parliamentary Commission, appointed to decide on the issue (considered to be of empire-wide concern), used it as a model for what was in reality India's first civil marriage law.

So far, it might appear as if this was a conflict entirely within the remit of British Church history, or at least within the history of sectarian politics within a strictly British context. But the introductory clause of the law intended to regulate 'marriages in India' belied the insularity that characterized the text of the law itself; by restricting its jurisdiction to marriages where at least one party professed to be of 'Christian religion', this law, which claimed a territorial scope in its title, exposed the manner in which religion was embedded in the category of 'British subject', for whom it was primarily intended. This religious qualifier served to simultaneously exclude the majority of Indians from its scope, and at the same time, include those people whose history has been to destabilize the secure separations of law and races. The commission was aware that there were Europeans in India who were Christians but who were not provided for, as there were East Indians, the latter being accommodated by considering them as being 'British subjects'. The most thorny problem, being the law regulating the marriages of those who had converted to Christianity from Hinduism or Islam, and who were in many cases repudiated by their spouses, was considered in great detail, but declared to be beyond the competence of the Commission, which decided to recommend a law only for the marriage of 'British subjects', however obscure the category. ${ }^{113}$

The Act for Marriages in India, legislated in $185^{114}$ embodied the efforts of the Commission, and produced the paradox of a confessionally-limited civil law, whereby parties of whom at least one was Christian, if they fulfilled the necessary conditions of minimum age (and/or consent of guardian), absence of a living spouse, and not being related within prohibited degrees, could, after due notice to the Marriage Registrar, have a purely civil marriage. The Government of India protested that the requirement of parental consent to marriage until the age of 21 would discriminate against Indian Christians, who might not have a congenial guardian ${ }^{115}$ (since their aggrieved parents

113 Report of the Royal Commission to inquire into State and Operation of Law of Marriages, pp. $367-370$.

114 An Act for Marriages in India, $14 \& 15$ Vic. Cap. XL of 1851.

115 Judicial Letters from India, 1852, pp. 171-173, L/PJ/3/291, APAC. 
were unlikely to offer consent) and be forced to postpone marriage until they were 21 (exceptionally late for marriage in nineteenthcentury India). The authorities in Britain failed to be moved by the exotic difficulties of their Indian co-religionists, and the Government of India was forced to enact Act $\mathrm{V}$ of $185^{2}$, replicating the British Parliamentary law. This law referred to Indian Christians only in passing: clauses 7 and 12 providing that 'native Christians' marrying under this law were to be made aware of the obligations arising out of it, most importantly that of monogamy. This reference presaged the sad fate of Zabardast Khan, included in the scope of law because he straddled classificatory categories incapable of comprehending the reality of his life.

\section{From Indian Marriage Act to Indian Christian Marriage Act: the sacralization of a civil law, 1864-1872}

Act V of $185^{2}$ in itself did not cause much concern to Indian Christians or to the missionaries who ministered to them, since most Indian Christians married in Church and remained unaffected by legal provisions for civil marriage.

But in 1864 , once again as part of its uniform civil code project, the Government of India attempted to create a 'universal'116 marriage law for India encompassing civil as well as Church marriages. This time, it caused uproar among missionaries, especially Roman Catholic priests from Madras presidency, who found that several of the provisions of proposed law conflicted with their established practices. The several offending aspects of Act XXV of 1864 included prescriptions regarding the performance of marriage ceremonies within daylight hours, the prohibited degrees of kinship, and also that of minimum age of the parties (thirteen for women and sixteen for men), and the requirement of parental consent where parties to a marriage were below the minimum age. ${ }^{117}$

Because of Catholic protests, the new Indian Marriage Act, V of 1865 made further modifications to the laws regulating Christian

116 Read: 'by exclusion Christian'.

117 Act XXV of 1864 and related papers have so far proved untraceable in the India Office Records; it appears that they were lent to the Colonial Office for reference. The present account is based on the papers relating to Act V of $186_{5}$, which described the failings of the previous law. 
marriages in India. Following recommendations from the Madras government, ${ }^{118}$ it removed the requirement of parental consent for all 'native Christians' (not only converts), and entirely exempted Roman Catholic marriages from the application of Part 5 which dealt with the conditions under which a marriage between 'native Christians' was valid:

That the bride was at least thirteen and the groom sixteen, That they should not be within prohibited degrees of consanguinity or affinity, That neither should have a spouse living,

That they take the marriage vow in a certain form, before two witnesses, And that the marriage should be celebrated within daylight hours.

But even with Roman Catholics (seemingly) out of the picture, ${ }^{119}$ the Indian Marriage Act needed further modifications before it could accommodate the requirements of Indian Christians. A now venerable Reverend Krishna Mohan Banerjea, as President of the Bengal Christian Association, complained bitterly against the removal of the requirement of parental consent for marriages of Christian minors. He urged that this left Indian Christian children as unprotected as orphans, liable to be misled into inappropriate marriages. Converts might require unusual freedom from parental control, but in his view, the children of converts certainly did not. In the final version of the marriage law of Christians in 1872 , which retained the minimum ages of thirteen and sixteen, the requirement of parental consent was re-added until the age of $21 .{ }^{120}$

Debates over a statutory minimum age of marriage and marital relations exercised over significant sections of the Indian public from the late-nineteenth century until well into the twentieth century. In their legal form these debates often replicated the apparent binary of natural law and religious law. It was the government's responsibility as well as its right to offer protection to vulnerable sections of Indian society, in this case, young girls, being evaluated against the doctrinal requirements of Hinduism and Islam, as well as the entitlement of Indians to protect their domestic space against encroachment by a

118 Government of Fort St George to Government of India, 17 January 1865, in Indian Marriage Act V of 1865 and connected papers, Government of India, Bills and Acts, $186_{5}$, Part $3, \mathrm{~L} / \mathrm{PJ} / 5 / 7$, APAC.

${ }^{119}$ Although subsequent discussion over divorce would reveal that their exemption was of unsure implication.

120 'Indian Marriage Act, 1872 and related papers' in Government of India, Bills and Acts, 1872 Part III, L/PJ/5/16, APAC. 
state being increasingly vilified as alien. ${ }^{121}$ In the Christian context, the debate took a different shape, with the 'universal' ideals of freedom (from religious or parental control) serving, unlike in the Hindu and Muslim context, to justify a lowering of the age of marriage. In conceptualizing the Indian Christian as essentially a convert from other religions, legislation sought to pre-empt punitive constraints that such religions might impose on the person exercising religious choice. But such a conflation of 'Christian' with 'convert' and of 'parental control' with 'hostile religious prescription' threatened to undermine the age and gender hierarchies within Christian families. Krishna Mohan's complaints have to be seen in this context. Being a 'convert' seemed unfairly to preclude being a sufficiently authoritative father.

\section{Christian monogamy and the travails of Indian Christians: the Native Converts' Marriage Dissolution Act, 1866}

We are now poised on the brink of explaining Zabardast Khan's failure to establish his status as a husband, in any law, whether Muslim or universal/Christian. As the British Parliamentary Commission was already aware in $185^{\circ}$, the most numerically substantial legal problem with regard to Christian marriage in India was the fact of religious change. They had examined with great curiosity the informal procedures adopted by missionaries in dealing with the thorny personal and marital dilemmas to which conversion to Christianity gave rise-learning that missionaries did not view conversion to Christianity as an end to the pre-Christian marriage, although this view was most often unreciprocated by the non-Christian spouse. Lengthy procedures were established, prohibiting re-marriage of the convert before adequate communication and persuasion had been

${ }^{121}$ These debates spilled over into a number of widely divergent ideological concerns, in which, as scholars have shown, the real experiences of women were treated as no more than the turf for male contests. See Tanika Sarkar, 'Conjugality and Hindu Nationalism: Resisting Colonial Reason and the Death of a Child-Wife' in Tanika Sarkar, Hindu Wife, Hindu Nation: Community, Religion and Cultural Nationalism (London: Hurst \& Co., 2001), pp. 191-225; Mrinalini Sinha, Colonial Masculinity: the 'Manly' Englishman and the 'Effeminate' Bengali in the Late Nineteenth Century (Manchester: Manchester University Press, 1995); Sudhir Chandra, Enslaved Daughters: Colonialism, Law and Women's Rights (Delhi: Oxford University Press, 1998). 
attempted, extending over a period of two to three years, only after which the convert was permitted to re-marry in church. ${ }^{122}$

Such church procedure of effecting divorces continued, in spite of the Commission's refusal to formalize it, but surfaced again within the range of official vision only when it was legally proscribed. The Act for Marriages in India, ${ }_{18} 5^{1}$ had prohibited marriage for Christians (including 'native' Christians) with a living spouse. And from $185^{2}$ onwards, the Government of India began receiving petitions from Indian converts to Christianity, complaining about their inability to remarry when deserted ${ }^{123}$ by their non-Christian spouses. But since the Act of $185^{1}$ dealt merely with civil marriages, it affected very few. However, with the extension of the same conditions to church marriages with the Indian Marriage Acts of 1864 and 1865 , Indian Christians, and those concerned with their spiritual welfare, found themselves in a quandary. With the passage of these laws, Christians who were already married committed the criminal offence of bigamy if they married again, even if their spouses had repudiated them, as was often the case with converts to Christianity. This gave Indian Christians, or at least Indian Christian men, an unwanted legal distinction, since polygamy was not illegal for any other category of Indian men. ${ }^{124}$ This situation, which would practically force the new convert to be celibate until the death of his/her spouse, was represented by Protestant and Catholic missionaries all over the country with great vigour as inequitable, and by the end of $186_{5}$, the Government of India had compiled an immense dossier of petitions, which requested a law permitting the dissolution of non-existent marriages in which Indian converts to Christianity remained trapped, a demand occasioned by the provisions of the most recent marriage law. ${ }^{125}$

${ }^{122}$ Minutes of Evidence given by David Hill, of the Judicial Department of the East India Company, in Report of the Royal Commission to inquire into State and Operation of Law of Marriages, pp. 379-381.

${ }^{123}$ But not divorced, since there was no divorce law applicable to Christians in India before 1866 .

124 Except Parsis after 1865 .

${ }^{125}$ Among the earliest petitioners was the Scottish Missionary, John Wilson, who worked in Bombay, and who referred to his experience with Parsi pupils who had converted to Christianity. Report of the Select Committee on the Bill to legalize, under certain circumstances, the re-marriage of native converts to Christianity, and associated papers, pp. 18-42, Government of India, Bills and Acts, $1866, \mathrm{~L} / \mathrm{PJ} / 5 / 8$, APAG. 
The Government of India was convinced of the justness of this appeal. Britain had in the very recent past legislated a divorce law, the Matrimonial Causes Act 1857 , but its provisions did not appear to fit the circumstances, since it focussed on sexual misdemeanour rather than religious conflict: adultery was a necessary ground for divorce under this law, on its own for the wife, and combined with other offences for the husband. Hence an entirely new law was drafted for India, using a provision from ecclesiastical law - that of suing for restitution of conjugal rights. Under the proposed law, the deserted spouse, as plaintiff, would demand the restoration of conjugal rights, and if the deserting non-Christian partner refused to comply, a divorce could be granted after the fulfilment of necessary procedures in court.

Most missionaries found the proposed law inconvenient. Reverend Fennelly, the Catholic bishop of the Madras, urged that the provisions of the proposed law were unnecessarily complicated and timeconsuming, as well as humiliating for women, since the procedure required the establishment of the fact of consummation in court. ${ }^{126}$ He strongly recommended that the Catholic church be permitted to follow its own canon law procedure for dissolving such marriages, which it had pursued so far, in India as well as in other countries. ${ }^{127}$ Taking a completely opposed point of view, urging prohibition rather than facilitation of divorce, urban Protestant Christian leaders of Calcutta and Delhi denounced the proposed law on the grounds that it would prevent reconciliations which in most cases did eventually take place, and would lead to a loss of opportunity to spread the Christian message further. Reverend Krishna Mohan Banerjea (once again) felt that the law was entirely the creation of missionaries who were totally unrepresentative of Indian Christians and who treated the latter as their serfs. ${ }^{128}$ Banerjea was to some extent unfair.

${ }^{126}$ Section 18 of the Act as it was passed in 1866 required establishing facts regarding consummation, which determined subsequent procedure.

${ }_{127}$ Government of India Legislative Proceedings, 18 August $186_{5}$, No. 39-4o, pp. 918-923, P/208/1 1, APAC. As the case of re Millard showed, the Catholic Church did insist on going its own way, with occasional adverse results for its members. A Catholic priest was convicted for abetting bigamy when he performed the marriage of a paraiyan (dalit or formerly untouchable caste) woman who had converted to Christianity in childhood, had married a non-Christian paraiyan man, and was subsequently abandoned by him. Indian Law Reports, re Millard, (1868) 10 Madras, 218-222. The case underlined forcefully the modern state's refusal to recognize alternative laws and tribunals with jurisdiction over marriage and its dissolution.

${ }^{128}$ From the Lord Bishop of Calcutta to the Viceroy of India, forwarding Krishna Mohan Banerjea's printed pamphlet, as well as letters from Tara Chand and Reverend 
Reverend R. Winter of the Anglican Society for the Propagation of Gospel's (SPG) mission to Delhi similarly stated that he didn't know of any Indian converts 'panting' to be re-admitted to marital life. ${ }^{129}$ On the other hand, Reverend W.T. Satthianadhan, of Madras, an Indian clergyman, responded to Banerjea (and Winter) that the scale of religious conversions in south India made the legal measure essential, implying that the righteous moral posture of north Indian and Bengali Christians arose from their being acquainted with an unrepresentatively small number of conversions. ${ }^{130}$

There were also petitions from Hindus and Muslims alleging that the law impinged on their religious rights under law. As a result, a number of provisions were modified, especially those requiring the physical presence of deserting wives in court. Muslims managed to secure a complete exemption from the law, on grounds that it was unnecessary, since a Muslim marriage was completely dissolved by apostasy, and also that it was invasive of Muslim personal law, since it forced the Muslim spouse to postpone re-marriage beyond the period of probation or iddat under Muslim law. ${ }^{131}$ This exemption was to lead to Zabardast Khan's judicial misfortune in 1870 , mentioned at the beginning of this paper.

\section{The Indian Divorce Act 1869, and the fate of Zabardast Khan}

When the Native Converts' Marriage Dissolution Act XXI of 1866 was passed, it proved incapable of addressing the marital problems of Indian Christians. The procedural requirements of this law necessitated that the deserting spouse be produced in court and subjected to a long process of interrogation and attempts at reconciliation. Where the spouse was untraceable, as was often the

R. Winter of the S. P. G. mission to Delhi, in, Report of the Select Committee on the Bill to legalize, under certain circumstances, the re-marriage of native converts to Christianity, and associated papers, pp. 18-42.

${ }^{129}$ Ibid., pp. 43-45.

${ }^{130}$ Ibid., pp. $5^{1-54}$. On Satthianadhan and the history of this illustrious Tamil Christian family, see E.M. Jackson, 'Glimpses of a Prominent Indian Christian Family of Tirunelveli and Madras, 1863-1 9o6: Perspectives on Caste, Culture, and Conversion' in R. E. Frykenberg (ed.), Christians and Missionaries in India: Cross-cultural Communication since I 500 (Michigan: W.B. Ferdmans, 2003), pp. 315 $5^{-335}$.

131 'Petition of the Mahomedan inhabitants of the town and suburbs of Calcutta', in Ibid., pp. 137-141. 
case, the law offered no remedy. ${ }^{132}$ But the Act of 1866 was not repealed. Instead, Act IV of 1869 , or the Indian Divorce Act, was legislated to supplement it as well as provide one more 'universal' law to complement the Indian Marriage Act. This law extended the provisions of the (English) Matrimonial Causes Act of 1857 , under which, as we have noted, adultery was a necessary condition for divorce, adultery of the wife being sufficient grounds, while adultery of the husband required additional grievances such as cruelty, desertion or 'unnatural' sexual acts. ${ }^{133}$ This time, the re-marriage of male converts' non-Christian wives was deemed equivalent to adultery. Similar behaviour by the non-Christian husbands of Christian women had to be construed differently, since English law did not as yet consider adultery by the husband as sufficient grounds for divorce. If such a husband had once been Christian, but had changed his religion, in order to re-marry, the combination of religious change and remarriage provided grounds for divorce. ${ }^{134}$ No relief was contemplated for the Christian woman whose repudiating husband had never been Christian, apart from what the Native Converts' Marriage Dissolution Act of 1866 could offer.

And so we find Zabardast Khan filing a suit for divorce, under the Indian Divorce Act, after his wife deserted him and Christianity for a Muslim husband and Islam. As mentioned at the beginning of this paper, Khan did not win his case, because the High Court judge decided that Khan's 'Muslim marriage' could not be dissolved under the Indian Divorce Act, which was intended for Christian, or at least monogamous marriages, not potentially polygamous ones. Neither could Khan use the older Native Converts' Marriage Dissolution Act,

132 This was pointed out by a judge from Dhaka, referring to a case where the deserting wife of a Christian convert had, subsequent to leading a 'dissolute' life, disappeared without trace. Under-Secretary to Government of India to Officiating Secretary Government of Bengal, $9^{\text {th }}$ September 1868 , acknowledging receipt of the letter with enclosure, Government of India Legislative Proceedings 1868, 12 September, No. 6, p. 274, P/436/55, APAC.

133 On the British divorce law, see J.H. Baker, An Introduction to English Legal History ( $3^{\text {rd }}$ edn, London: Butterworths, 1990), pp. 567-568; Lawrence Stone, Road to Divorce: England 1530-1987 (Oxford: Clarendon, 1990), pp. 353-390; Olive Anderson, 'Hansard's Hazards: an Illustration from Recent Interpretations of Married Women's Property Law and the 1857 Divorce Act' in The English Historical Review, Vol. 11 2, No. 449 (November 1997), pp. 1202-1215.

${ }_{134}$ Henry Rattigan, The Law of Divorce Applicable to Christians in India (the Indian Divorce Act) ( $2^{\text {nd }}$ edn, Lahore: Unniversal Book Agency, 1936), p. 105. This provision was specific to Indian law, with no counterpart in British law, since under British law a second marriage was necessarily a criminal offence. 
since deserting Muslim spouses (such as his wife) were expressly exempted from its provisions. It will be recalled that when exempting Muslims from the Native Converts' Marriage Dissolution Act XXI of 1866 , the government had been convinced that Muslim marriages were dissolved by the conversion of any one spouse. This remained the view of the Muslim legal specialist consulted in this case, but that did not help Khan, since it appeared to the judge that as a Christian, he was not entitled to benefit from the provisions of Muslim personal law. ${ }^{135}$

A similar decision was reached by the Madras High Court in Thapitha Peter versus Thapitha Lakshmi. One of the three judges in that case was Muthusamy Aiyar, the first Indian to be appointed to the High Court in Madras. ${ }^{136}$ These judges decided that the Indian Divorce Act did not apply to a Hindu marriage, even if the parties themselves had both become Christians, because the Indian Divorce Act was not meant to apply to polygamous marriages (as with Khan) and also because the court had no jurisdiction to hear matrimonial disputes of Hindus. Since matrimonial jurisdiction of the High Courts was derived from the ecclesiastical jurisdiction of the erstwhile Supreme Courts, matrimonial causes relating to non-Christian marriages could not be heard in these courts. ${ }^{137}$ The principle that the Indian Divorce Act could not dissolve non-Christian marriages held for at least another half-century until, in 1912, the Calcutta High Court ruled that, if the plaintiff was Christian at the time of the suit, the Indian Divorce Act could apply. ${ }^{138}$

In the early-twentieth century, a newly-formed Christian (mostly Protestant) political organization with India-wide membership, called the All Indian Conference of Indian Christians, voiced animated complaints against a marriage law that permitted, according to them, undeterred adultery by Christian women in India. ${ }^{139}$ I found this complaint baffling, not least because I found it hard to

135 Zaburdust Khan versus his wife (1870) 2 N.W. 370.

136 M. P. Duraisamy Aiyar, Memories of Sir T. Muthusami Ayyar: First Indian Judge of the High Court of Madras (Tanjore, n.d. [1912]).

137 Thapitha Peter versus Thapitha Lakshmi, Indian Law Reports (1894), 17 Madras, pp. $235^{-246 .}$

138 Henry Rattigan, The Law of Divorce, pp. 34-35.

${ }^{139}$ B. N. Athavale, 'The present law regarding Indian Christians-is legislation necessary?', The Report of the First Session of the All India Conference of Indian Christians, held in Calcutta, December I9I4 (Madras, 1915), Appendix I, United Theological College Archives, Bangalore. Athavale was not aware of the recent Calcutta judgement: it was pointed out in subsequent meetings of the A.I.C.I.C. 
believe this self-portrayal by Christian men as victimized, constantly cuckolded husbands. Unless Indian Christian middle-class women were remarkably unlike middle-class women of other communities, there was obviously more going on than the political narrative of this community revealed. An investigation into the actual cases cited led me into the complex story of religious change, personal and social conflicts, and legal negotiations narrated above.

\section{Conclusion}

In this paper, I have offered answers to two distinct historical questions, one substantive, the other speculative. The first question is about the origins of Christian personal law as a distinct set of judiciable rules regarding family relations and property, apparently premised on religion. The second question frames the first, querying how a notion of confessionally differentiated laws came to be shaped and applied in colonial India, and how such a legal concept was connected to specific elements within it, such as Christian personal law. I have argued that the notion that familial and property relations were the exclusive jurisdiction of legislative and judicial organs of the state produced a novel situation in late-eighteenth-century India, as the British colonial regime shaped itself in Bengal and other peripheral zones of the declining Mughal empire. Into such a new institutional and ideological context fed earlier ('pre-colonial') British efforts to legally deal with the fact of religious and cultural differences in India, and also increasingly more pressing needs to distinguish the British (the rulers) from those whom they ruled. The distinction and hierarchization of those who were different within the universalistic notion of rule of law produced a peculiarly modern state-centred legal regulation of difference, incomprehensible within Mughal notions of law and justice.

I have deliberately used the history of (apparently) marginal Indian groups in order to reveal the ideas and paradoxes that lay beneath the system of personal laws. It was such groups that forced the colonial legal regime to reconsider the adequacy of its categorical binaries: British-native, Hindu-Muslim, and also to search for substantial means to make the notion of universal civil rights and religious freedom available to groups that simply did not fit legal typologies. It is ironic that the result of this quest to resolve difference with universality, resulted in further differentiating a group of people as 
Indian Christians, for whom an entire personal law appeared to spring from the earth.

Yet, in spite of the fact that the statutes framing Christian personal law were legislated in a cluster in a few decades from the mid- to the late-nineteenth century, this did not reflect the arbitrary and unilateral will of a colonial regime. In repeatedly referring to the personal laws as a system, rather than as an aggregation of the fragments of several religious laws, I have attempted to indicate how the principle of preservation of Indian laws, and non-interference in Indian religion, provided a political platform which came to be rapidly occupied by novel Indian speakers who, in claiming to represent their religious communities, revealed modern, horizontally conceptualized and lay-oriented notions of religion and human collectives. The leaders of such collectives asserted the claims of 'their' religions against each other, as well as against any attempts by the state to create a religionneutral legal zone of personal and property rights. It was the historical role of Christians, who came to be perceived as the rule-breakers of every community, to provide repeated occasions for evaluating what remained of the universal project, even if universality in colonial India ultimately became provincialized into a community's personal laws.

It has been difficult to write a legal history in which the will of none of the principal protagonists matched the ultimate outcome. Law has often been seen as a vehicle of political ideology, or in a more diffuse sense, of coherent visions of culture and society.

In tracing the story of Christian personal law in India, I have read several such apparently coherent statements, for example, about the illegitimacy of individual will in Hindu and Muslim property relations. In reading these statements, I could not but notice their precise polemical purpose, and also their connection with less clearly stated but equally purposeful actions, such as the creation of private Hindu religious trusts to exclude errant sons, especially those who had dared to change their religion. Christians themselves projected a variety of social visions, if their claims in the context of legal disputes can at all be read as such. While they repeatedly referred to the universalistic notion of religion-neutral civil rights by invoking the lex loci, they did so primarily in order to claim connection with a particular personal law, which often happened to be that version of the Hindu law which offered disproportionately greater privileges to men than to women.

The result of this inherently competitive process was the Christian personal law, with its peculiarities, which appear simultaneously discriminatory against Christian women, and also against Christians 
in general as compared with other religious communities. ${ }^{140}$ This paper has attempted to explain these paradoxical features by arguing that the history of Christian personal law consisted not merely of systematic discrimination against a religious community, but also of efforts to define the membership of that 'community' and the nature of inter-personal relations within it, and a persistent quest for universal legal principles in the midst of acknowledged legal differences.

${ }^{140}$ Such as the requirement to register any bequest to a religious institution a year in advance, or the loss of custody by a Hindu following conversion. 